\title{
Climate Policy Modeling: An Online SCI-E and SSCI Based Literature Review
}

\author{
Yi-Ming Wei a, b, *, Zhi-Fu Mi ${ }^{\text {a, b }}$, Zhimin Huang a, c \\ ${ }^{a}$ Center for Energy and Environmental Policy Research, Beijing Institute of Technology, \\ Beijing 100081, China \\ b School of Management and Economics, Beijing Institute of Technology, Beijing \\ 100081, China \\ ${ }^{c}$ Management School of Business, Adelphi University, Garden City, New York 11530, \\ US
}

ABSTRACT: This study utilizes the bibliometric method on climate policy modeling based on the online version of SCI-E from 1981 to 2013 and SSCI from 2002 to 2013, and summarizes several important research topics and methodologies in the field. Publications referring to climate policy modeling are assessed with respect to quantities, disciplines, most productive authors and institutes, and citations. Synthetic analysis of keyword frequency reveals six important research topics in climate policy modeling which are summarized and analyzed. The six topics include integrated assessment of climate policies, uncertainty in climate change, equity across time and space, endogeneity of technological change, greenhouse gases abatement mechanism, and enterprise risk in climate policy models. Additionally, twelve types of models employed in climate policy modeling are discussed. The most widely utilized climate policy models are optimization models, computable general equilibrium (CGE) models, and simulation models.

KEYWORDS: Climate policy, Integrated assessment, Enterprise risk, Bibliometric, Word frequency analysis

\section{Introduction}

Since the United Nations Framework Convention on Climate Change (UNFCCC) and the Kyoto Protocol were set forward, numerous climate policies have been introduced to

\footnotetext{
* Corresponding author.Tel.: +86 1068918651.

E-mail address: wei@bit.edu.cn (Y.-M. Wei).
} 
mitigate climate change. Climate change has been a complex collection of political, economic, environmental, and even moral issues rather than a purely scientific issue over the last few decades [1-4]

We believe that climate policy models have played a significant role in studies of climate policy assessment. First, many influential reports have employed climate policy models. The PAGE model [5], for instance, was employed in the Stern Report released by the United Kingdom in 2006 [6]; IPCC also utilized a number of climate policy models in their assessment reports [7]. Second, an increasing number of papers in this field have published in the most influential academic journals in the past few years. For example, discussions of uncertainty in climate policy models by Murphy et al. [8] and Stocker [9] were published in Nature. Reviews of climate change integrated assessment models by Dowlatabadi and Morgan [10] as well as a paper on American climate policy modeling progress by Kerr [11] were published in Science. The paper using the DICE model to compare global warming polices by $\mathrm{Hu}$ et al. [12] and the paper employing a risk-neutral reduced-form model to analyze $\mathrm{CO}_{2}$ emissions allowance prices by Carmona and Hinz [13] were published in Management Science. The paper which used Data Envelopment Analysis (DEA) model to examine the legal validity of US Clean Air Act [14] and the paper which used Bayesian approach to optimally size photovoltaic system under climate change [15] were published in Omega.

Previous work on climate policy models was reviewed from different perspectives. Dowlatabadi and Morgan [10] argued that the causes, processes and results of climate change should be assessed using climate policy models. They also summarized the development of the integrated assessment models and have introduced several models including IMAGE, DICE, CETA, PAGE and ICAM-0/ICAM-1. Dowlatabadi [16] summarized eighteen climate policy models and classified them into three categories: the cost-effectiveness framing, the cost-impact framing, and the cost-benefit framing. Sen et al. [17] developed a progress map of integrated assessment models (IAMs) for climate policy and discovered the obstacles in developing this type of model. Wang et al. [18] introduced several models used in climate policy assessment, including the input-output model, the computable general equilibrium (CGE) model, the macro econometrics model, the engineering economic model, the dynamic 
energy optimization model, the energy system simulation model and the integrated assessment model. Wei et al. [19] summarized 29 existing climate change integrated assessment models (IAMs), and discussed the progress of IAMs for climate policy.

The bibliometric approach has been widely used to assess the performance of a certain research field [20-24]. Wu and Olson [25] used Scopus and ISI Web of Science to analyze the enterprise risk management area. The results showed that published papers in this area continued to increase from 2000 to 2012. Holsapple and Lee-Post [26] utilized bibliometrics to analyze the knowledge dissemination channels in operations management. A new behavior-based approach was developed in this paper to rank journals relevant to operations management research. In recent years, bibliometric analysis was employed in climate change research. Li et al. [27] evaluated the research progress, the development trend and the methodology of climate change research from 1992 to 2009 by means of bibliometric analysis based on the online version of SCI-E. Bjurstro and Polk [28] analyzed 6417 articles from 96 journals that were most widely utilized in the third IPCC assessment reports. They learned that research of climate change in physics, biology and social science was focused within each obviously discipline. There was a long way to go for real cross-disciplinary research in the area of climate change. Hsu and Wang [29] used the ProQuest database to analyze whether market valued corporate response to mitigate climate change. The empirical results showed that the socially responsible action to tackle climate change was costly, and firms with more negative words on climate change had significantly positive wealth effects.

The main objective of this study was to explore the most interesting research topics and methodologies in the field of climate policy modeling. First of all, the bibliometric method was used to describe the latest research status, including disciplines statistics, authors statistics, institutions statistics, journals statistics, and article citations. Second, the frequency analysis of keywords was used to discover the most interesting research topics and methodologies in this field. Ultimately, several suggestions pertaining to climate policy modeling were given in the conclusion. It should be noted that part of this paper has appeared in two published Chinese articles. The first article contained the bibliometric analysis of climate policy modeling from 1981 to 2012 [30]. In this paper, we updated the data to 2013. Partial contents of section 4 and 5 appeared in the other article which introduced the progress 
of climate change integrated assessment models [19].

\section{Methodology}

The data used in this study was obtained from the online version of SCI-E from 1981 to 2013 and SSCI from 2002 to 2013. The data was obtained on the $24^{\text {th }}$ of September 2014. We selected documents containing, in the TS (topic) section, the descriptors of "climate change", "policy" and "model":

TS=(("climate change" OR "climate changes" OR "climatic change" OR "climatic changes" OR "climate variability" OR "environmental change" OR "environmental changes" OR "global warming" OR "sea-level rise" OR "sea-level rising" OR "extreme climate" OR “extreme weather” OR "low carbon" OR GHG OR “Greenhouse Gas" OR CO2 OR “carbon dioxide" OR "carbon emission" OR "carbon permit" OR "carbon market" OR "carbon finance" OR "carbon leakage" OR "carbon footprint” OR CDM OR "Clean Development Mechanism" OR (climate sensitivity) OR (climate resilience) OR (climate vulnerability) OR (climate impact) OR (climate mitigation) OR (climate adaptation)) AND (policy OR policies) AND model*).

Keywords contain the most critical information in most articles. So the frequency analysis of keywords was used to discover the most interesting research topics and methodologies in climate change modeling. At first, we got the frequencies of keywords for each year. After that, we tried to summarize the interesting research topics and methodologies in this field manually. Fig. 1 shows the research framework of this study. It should be noted that "China" in this study refers to the Mainland China only, and the articles from Hong Kong, Macao and Taiwan are excluded. UK refers to England, Scotland, Northern Ireland and Wales. 


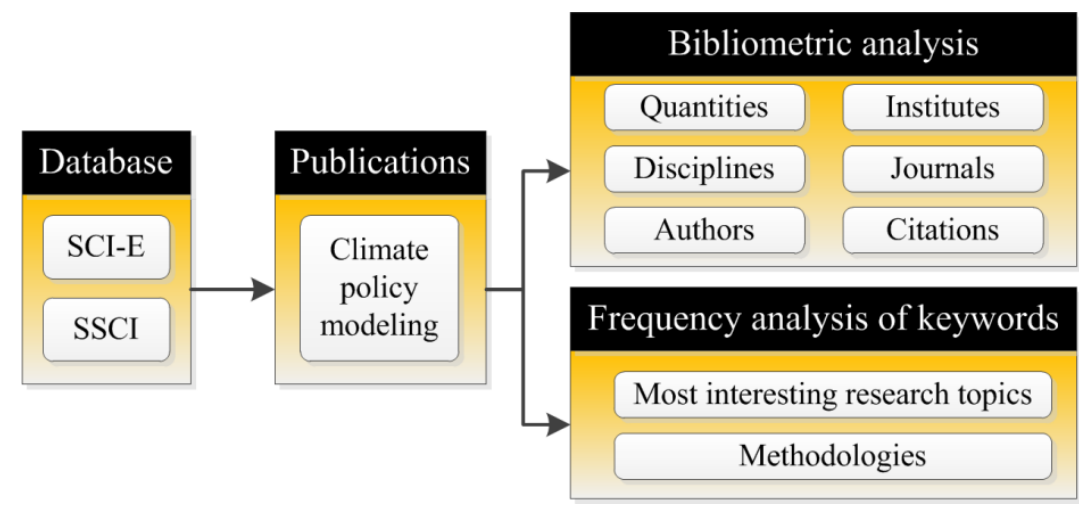

Fig. 1. The research framework of this paper.

\section{Literature overview}

\subsection{General statistics}

According to the result, there are 5733 publications on climate policy modeling. Fig. 2 illustrates the dramatic increase of published articles in climate policy modeling. Three papers [31-33] were published from 1984 to 1990 . The development process can be divided into two stages: stage 1 was from 1984 to 2000 in which academic development was stable and stage 2 was from 2001 to 2013 in which academic publications grew at a much faster rate. The average annual growth rate in the stage 2 is $26.71 \%$. In addition, the withdrawal of the United States from the Kyoto Protocol in 2001, as well as the publication of the IPCC third assessment report [34], attracted research from countries all over the world. These occurrences also contributed to the increase of publications in climate policy modeling. 


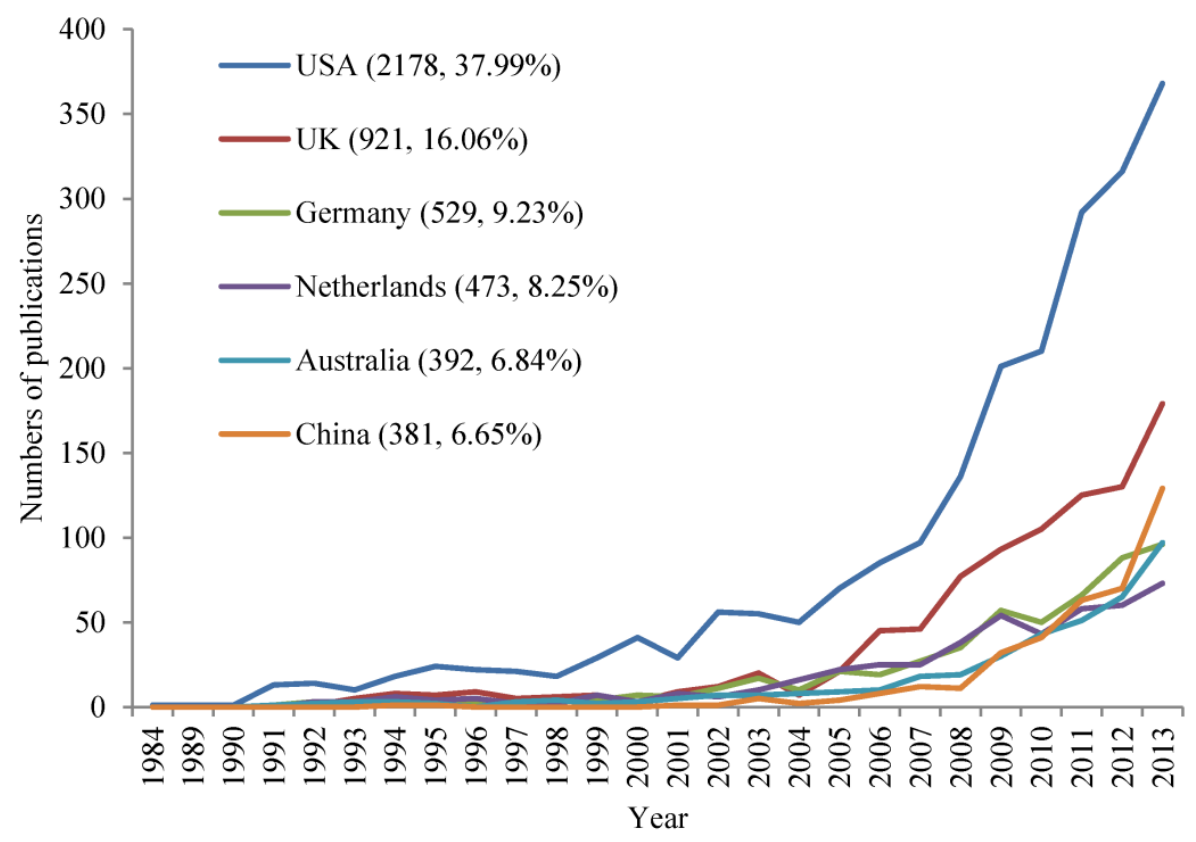

Fig. 2. Timeline of climate policy modeling publications.

Note: This figure is adapted from [30]. The figures in parentheses refer to the cumulated numbers of publications and their proportions in global publications.

\subsection{Disciplines statistics}

Climate policy modeling is an interdisciplinary area. According to the SCI-E and SSCI database, three hundred and thirty-two subject categories are involved in this area. They can be divided into several disciplines, including environmental sciences, economics, geosciences, meteorology \& atmospheric sciences, ecology, management sciences, and others. Most publications come from the discipline of environmental sciences, which accounts for $49.94 \%$ of the publications (see Fig. 3). 


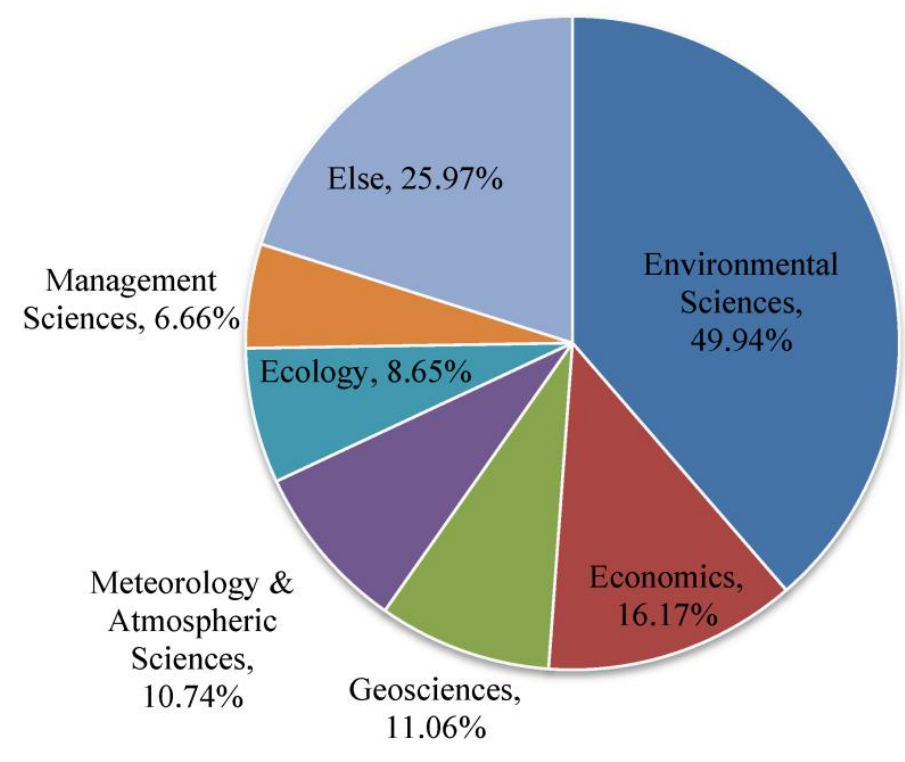

Fig. 3. Disciplines involved in the climate policy modeling.

Note: This figure is adapted from [30]. The figures in parentheses refer to the disciplines' percentages of all papers. One paper may belong to two or more disciplines, so the sum of all percentages is more than $100 \%$.

\subsection{Authors statistics}

Table 1 shows the top ten most productive authors in climate policy modeling. The results indicate that in the field of climate policy modeling, JM Reilly from the Massachusetts Institute of Technology (MIT) has published the most journal articles. He also has the highest H-index.

Table 1 The most productive authors in the climate policy modeling.

\begin{tabular}{lllllll}
\hline & Author & Country & Number of productions & Number of citations & C/P & H-index \\
\hline 1 & JM Reilly & USA & 51 & 1188 & 23.29 & 18 \\
2 & GH Huang & China & 40 & 702 & 17.55 & 17 \\
3 & RSJ Tol & Netherlands & 38 & 885 & 23.29 & 15 \\
4 & DP Van Vuuren & Netherlands & 36 & 1379 & 38.31 & 16 \\
5 & S Paltsev & USA & 35 & 582 & 16.63 & 12 \\
6 & O Edenhofer & Germany & 23 & 453 & 19.70 & 11 \\
7 & M Tavoni & Italy & 22 & 411 & 18.68 & 10 \\
8 & K Riahi & Austria & 20 & 1315 & 65.75 & 12 \\
9 & M Obersteiner & Austria & 19 & 392 & 20.63 & 8 \\
9 & C Hope & UK & 19 & 225 & 11.84 & 8 \\
\hline
\end{tabular}

Note: This table is adapted from [30]. Country refers to the country where the first author's institution is located. $\mathrm{C} / \mathrm{P}$ infers to number of citations per publication. The $\mathrm{H}$-index is based on the number of papers of one author that are collected from the 5733 papers in this study rather than the total number of papers the author has published, so the H-index is to measure the productivity and impact of the authors in the field of climate policy modeling. 


\subsection{Institutions statistics}

According to our database, 7727 different institutions are involved, among which Massachusetts Institute of Technology (MIT) is ranked number one with a total of 125 papers (see Table 2).

Table 2 The most productive institutions in the climate policy modeling.

\begin{tabular}{|c|c|c|c|c|c|}
\hline & Institution & Type & Country & $\begin{array}{l}\text { Number of } \\
\text { productions }\end{array}$ & Percentage $(\%)$ \\
\hline 1 & MIT & University & USA & 125 & 2.18 \\
\hline 2 & UNIV CALIF BERKELEY & University & USA & 115 & 2.01 \\
\hline 3 & VRIJE UNIV AMSTERDAM & University & Netherlands & 105 & 1.83 \\
\hline 4 & INT INST APPL SYST ANAL & NGO & Austria & 99 & 1.73 \\
\hline 5 & UNIV OXFORD & University & UK & 91 & 1.59 \\
\hline 5 & UNIV CAMBRIDGE & University & UK & 91 & 1.59 \\
\hline 6 & CHINESE ACAD SCI & $\begin{array}{l}\text { Governmental } \\
\text { organization }\end{array}$ & China & 85 & 1.48 \\
\hline 7 & $\begin{array}{l}\text { POTSDAM INST CLIMATE } \\
\text { IMPACT RES }\end{array}$ & $\begin{array}{l}\text { Governmental } \\
\text { organization }\end{array}$ & Germany & 84 & 1.47 \\
\hline 8 & CARNEGIE MELLON UNIV & University & USA & 83 & 1.45 \\
\hline 9 & UNIV MARYLAND & University & USA & 78 & 1.36 \\
\hline
\end{tabular}

Note: This table is adapted from [30]. NGO refers to non-governmental organization. Percentage refers to the ratio of publications in one institute to all publications.

\subsection{Journal statistics}

Among the top ten journals that have the most publications in climate policy modeling, four are from the UK, three are from Netherlands, and one is from the USA (see Table 3). These journals primarily come from the fields of environmental science, energy, and economics. In particular, Energy Policy is the most productive journal with 541 papers (accounting for $9.44 \%$ of all papers).

Table 3 Journals that have the most publications in the climate policy modeling.

\begin{tabular}{lllllll}
\hline & Journal & $\begin{array}{l}\text { Number of } \\
\text { publications }\end{array}$ & $\begin{array}{l}\text { Percentage } \\
(\%)\end{array}$ & IF & Country & Subject Categories \\
\hline $1 \quad$ Energy Policy & 541 & 9.44 & 2.696 & UK & $\begin{array}{l}\text { Energy \& Fuels, } \\
\text { Environmental Studies }\end{array}$ \\
& Climatic Change & 282 & 4.92 & 4.622 & Netherlands & $\begin{array}{l}\text { Environmental Sciences, } \\
\text { Meteorology \& }\end{array}$ \\
& & & & & Atmospheric Sciences \\
\hline
\end{tabular}




\begin{tabular}{|c|c|c|c|c|c|c|}
\hline 3 & Energy Economics & 192 & 3.35 & 2.580 & Netherlands & Economics \\
\hline 4 & Ecological Economics & 150 & 2.62 & 2.517 & Netherlands & $\begin{array}{l}\text { Ecology, Environmental } \\
\text { Sciences }\end{array}$ \\
\hline 5 & $\begin{array}{l}\text { Global Environmental } \\
\text { Change- Human and } \\
\text { Policy Dimensions }\end{array}$ & 99 & 1.73 & 6.000 & UK & Environmental Sciences \\
\hline 6 & Energy & 90 & 1.57 & 4.159 & UK & $\begin{array}{l}\text { Thermodynamics, } \\
\text { Energy \& Fuels }\end{array}$ \\
\hline 7 & Climate Policy & 81 & 1.41 & 1.703 & UK & $\begin{array}{l}\text { Environmental Studies, } \\
\text { Public Administration }\end{array}$ \\
\hline 8 & $\begin{array}{l}\text { Environmental } \\
\text { Science \& Policy }\end{array}$ & 77 & 1.34 & 3.514 & USA & Environmental Sciences \\
\hline 9 & $\begin{array}{l}\text { Environmental } \\
\text { Science \& }\end{array}$ & 75 & 1.31 & 5.481 & USA & $\begin{array}{l}\text { Environmental } \\
\text { Engineering, }\end{array}$ \\
\hline 10 & $\begin{array}{l}\text { Technology } \\
\text { Energy Journal }\end{array}$ & 66 & 1.15 & 1.864 & USA & $\begin{array}{l}\text { Environmental Sciences } \\
\text { Energy \& fuels }\end{array}$ \\
\hline
\end{tabular}

Note: This table is adapted from [30]. Percentage (\%) refers to the ratio of publications in one journal to all publications. IF refers to impact factor of 2013.

\subsection{Article citations}

The most highly cited article was published in Nature in 2010, which was cited by 662 times [35]. The article was co-authored by nineteen authors who came from thirteen different institutes. As the first author and corresponding author, RH Moss is a scientist with the PNNL Joint Global Change Research Institute at the University of Maryland. Table 4 illustrates the top ten most highly cited articles.

Table 4 The most highly cited articles in climate policy modeling.

\begin{tabular}{|c|c|c|c|c|c|c|}
\hline & Author & Year & Journal/ Conference & $\begin{array}{l}\text { Total } \\
\text { citations }\end{array}$ & $\mathrm{C} / \mathrm{Y}$ & Country \\
\hline \multirow[t]{3}{*}{1} & Moss et al. [35] & 2010 & Nature & 662 & 132.40 & USA \\
\hline & & & Proceedings of the National & & & \\
\hline & & & Academy of Sciences of the & & & \\
\hline 2 & Lenton et al [36] & 2008 & United States of America & 576 & 82.29 & UK \\
\hline \multirow[t]{2}{*}{3} & Katz and Brown [37] & 1992 & Climatic Change & 510 & 22.17 & USA \\
\hline & & & American Journal of Preventive & & & \\
\hline 4 & Sallis et al. [38] & 1998 & Medicine & 482 & 28.35 & USA \\
\hline 5 & $\begin{array}{l}\text { Giorgi and Mearns } \\
\text { [39] }\end{array}$ & 1991 & Reviews of Geophysics & 416 & 17.33 & USA \\
\hline 6 & Alley et al. [40] & 2003 & Science & 409 & 34.08 & USA \\
\hline 7 & Stern $[41]$ & 2004 & World Development & 403 & 36.64 & USA \\
\hline
\end{tabular}




\begin{tabular}{|c|c|c|c|c|c|c|}
\hline 8 & Unruh [42] & 2000 & Energy Policy & 389 & 25.93 & Spain \\
\hline 9 & Duarte [43] & 2002 & Environmental Conservation & 363 & 27.92 & Spain \\
\hline 10 & Held and Soden [44] & 2000 & $\begin{array}{l}\text { Annual Review of Energy and } \\
\text { the Environment }\end{array}$ & 362 & 24.13 & USA \\
\hline
\end{tabular}

Note: This table is adapted from [30]. Country refers to the country where the first author's institution is located. $\mathrm{C} / \mathrm{Y}$ refers to the number of citations per year.

\section{Most interesting research topics and key research issues on climate policy modeling}

Keywords contain the most critical information in most articles. Consequently, this enables us to discover the most interesting research topics through frequency analysis of keywords. Based on the results of keyword frequency, six of the most interesting research topics of climate policy modeling are obtained. They include integrated assessment of climate policies, uncertainty in climate change, equity across time and space, endogeneity of technological change, greenhouse gases abatement mechanism, and enterprise risk in climate policy models (see Fig. 4).

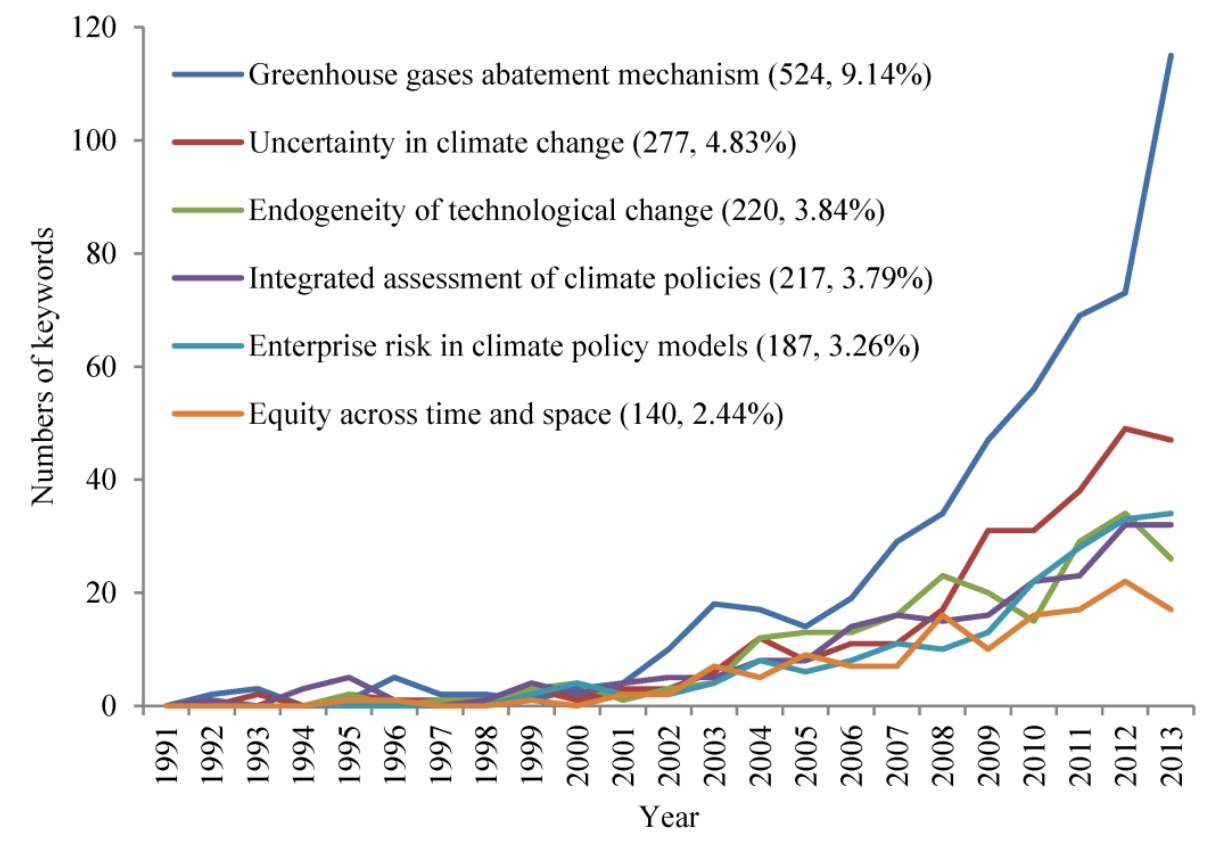

Fig. 4. Most interested research topics of climate policy modeling.

Note: This figure is adapted from [30]. The figures in parentheses refer to the cumulated numbers of keywords to the corresponding research topics and their proportions in all publications. 


\subsection{Integrated assessment of climate policies}

Climate change impacts the social system as well as the natural system. In order to solve climate change problems, it is necessary to combine natural science and social science into a model framework. In this way, the impacts of climate policies can be assessed more accurately. Therefore, climate change integrated assessment model (IAM) which usually includes climate submodels and economic submodels was introduced. Nordhaus [45] integrated an economic system and a climate system into a model framework to assess climate policies, which marked the beginning of the climate change IAM model.

Then, IPCC Assessment Report [7, 34] accepted the advantages of IAMs, and many IAMs made great contributions to this report. On the other hand, the objective of the United Nations Framework Convention on Climate Change (UNFCCC) is to achieve "stabilization of greenhouse gas (GHG) concentrations in the atmosphere at a level that would prevent dangerous anthropogenic interference with the climate system." Thus, the IAM models are needed to assess the effects of climate policies on the climate system. Consequently, IAMs have had a rapid development, and have become the most popular analysis framework in climate policy assessment. In the future, IAMs will be transformed into a hybrid model incorporating a computable general equilibrium model of the world economy, three-dimensional models of atmospheric chemistry and dispersal, a coupled ocean-atmosphere global circulation model, general coupled ecological systems models, and models of social preferences and dynamics [10].

Most IAMs which have an abatement function and a damage function are based on cost-benefit analysis. They obtain the optimal path for controlling GHGs by maximizing the discounted present value of welfare. The assessment of climate policy in IAMs usually includes six steps (see Fig. 5): (1) Projecting the future GHG emissions under a "business as usual" (BAU) scenario and one or more abatement scenarios, and obtaining future GHG concentrations; (2) Projecting the global temperature based on the GHG concentrations; (3) Assessing the losses of GDP or income because of higher temperature; (4) Assessing the costs of GHG emissions abatement; (5) Assessing abatement benefits based on the assumption of social unity and rate of time preference; (6) Analyzing the costs of abatement and determining 
the future gains from reduced warming. This is essentially the approach of DICE [46], RICE [47], CETA [48], and PAGE [6].

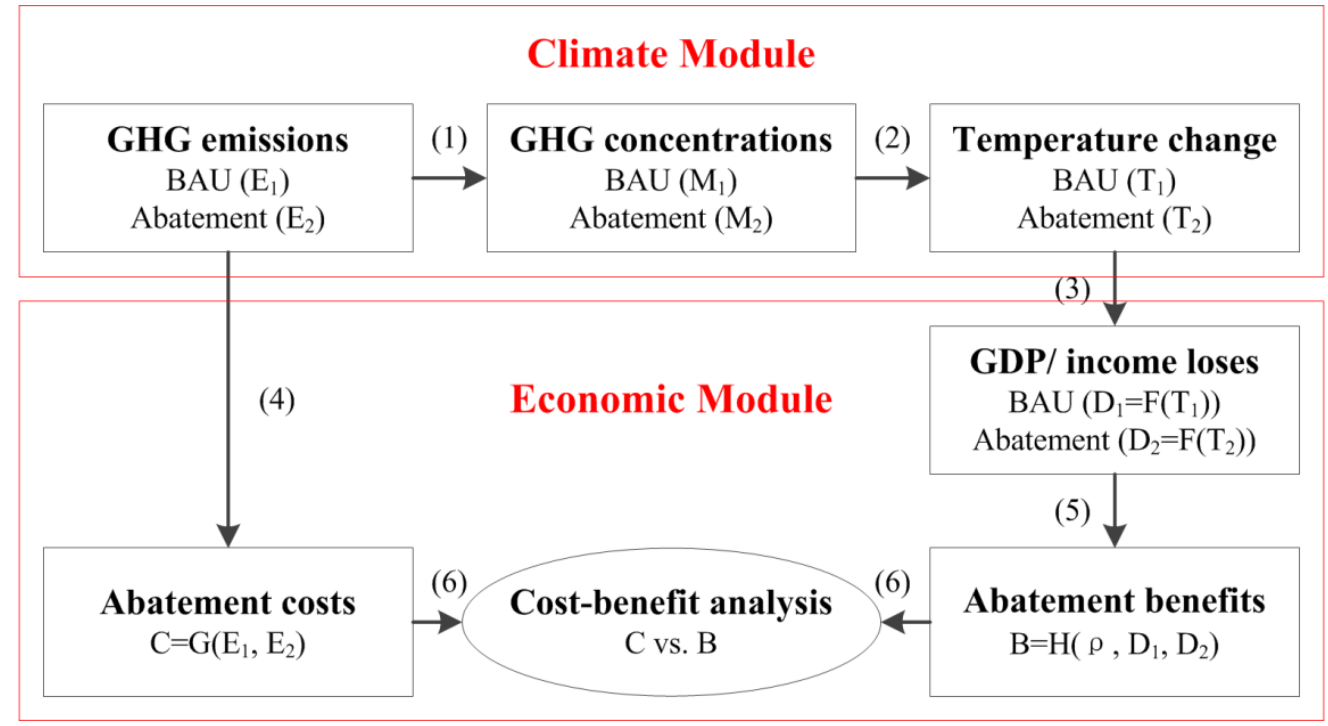

Fig. 5. Framework of integrated assessment models.

Note: This figure is adapted from [19]. E, M, T, C, D, B and $\rho$ are GHG emissions, GHG concentrations, temperature, abatement costs, losses of GDP or income, abatement benefits, and rate of time preference, respectively. F, G and $\mathrm{H}$ are the damage function, the abatement function, and the unity function, respectively. BAU and abatement are "business as usual" scenario and abatement scenario, respectively.

\subsection{Uncertainty in climate change}

Uncertainty abounds in climate change, and dealing with uncertainty is an important factor in climate policy modeling. The sources of uncertainty in climate policy modeling can be distinguished by the following five aspects: (1) Inherent randomness of nature: the non-linear, chaotic and unpredictable nature of natural processes. (2) Value diversity: differences in people's mental maps, world views and norms and values. (3) Human behavior (behavioral variability): "non-rational" behavior, discrepancies between what people say and what they actually do (cognitive dissonance), or deviations of 'standard' behavioral patterns. (4) Social, economic and cultural dynamics (societal variability): the non-linear, chaotic and unpredictable nature of societal processes. (5) Technological uncertainty: new developments or breakthroughs in technology or unexpected consequences ("side-effects") of technologies [49]. Faced with these uncertainties, some papers attempt to describe and classify the uncertainties [50-53], while others try to quantify them subjectively [54, 55]. Table 5 shows 
several models which explicitly incorporate uncertainties into their model structure.

Uncertainty in climate change results in the uncertainty of costs and benefits of climate policy, which creates a significant challenge to many climate policy models which are based on the cost-benefit analysis (CBA) [46-48, 56]. Stern [57] considered that there were uncertainties that prevented precise quantification of the economic impacts and there was a serious risk of major, irreversible change with non-marginal economic effects. Therefore, the marginal method in traditional models was inappropriate in climate change research. Weitzman [58] argued that there were important structural uncertainties in climate change which obeyed fat-tailed distributions. The uncertainty would be so large that expected utility maximisation is either undefined or arbitrary, which is known as Weitzman's Dismal Theorem [59, 60]. Most cost-benefit analysis models, however, were based on the normally-distributed uncertainties. Therefore, these models underestimated the probability and degree of climate disasters in the future.

In order to deal with uncertainty in climate change, climate policy models in the future need to address the following questions: the probability distribution of the effects of climate change, the degree to which human society is risk averse, and the rate at which human society discounts future benefits and costs relative to those in the present [61].

Table 5 Models which explicitly incorporate uncertainty in the model structures.

\begin{tabular}{|c|c|c|c|c|}
\hline Model & Model type & $\begin{array}{l}\text { Type of uncertainty } \\
\text { analysis }\end{array}$ & Uncertainty factor & Reference \\
\hline CETA & Optimization & $\begin{array}{l}\text { Sequential decision making } \\
\text { under uncertainty }\end{array}$ & $\begin{array}{l}\text { Warming per } \mathrm{CO}_{2} \text { doubling; } \\
\text { Level parameter in damage function; } \\
\text { Power parameter in damage function }\end{array}$ & {$[62]$} \\
\hline DICE & Optimization & $\begin{array}{l}\text { Monte Carlo analysis } \\
\text { (using representative } \\
\text { scenarios); } \\
\text { Sequential decision making } \\
\text { under uncertainty }\end{array}$ & $\begin{array}{l}\text { Rate of population growth; } \\
\text { Productivity growth; } \\
\text { Discount rate; } \\
\text { GHG-output ratio; } \\
\text { Damage function intercept; } \\
\text { Climate-GHG sensitivity; } \\
\text { Atmospheric detention rate; }\end{array}$ & {$[63]$} \\
\hline FUND & Optimization & $\begin{array}{l}\text { Monte Carlo analysis; } \\
\text { Propagation of selected } \\
\text { parameters }\end{array}$ & $\begin{array}{l}\text { Socio-economic drivers; } \\
\text { Climate change impacts; } \\
\text { Emissions reduction }\end{array}$ & {$[64]$} \\
\hline
\end{tabular}




\begin{tabular}{|c|c|c|c|}
\hline MERGE & Optimization & $\begin{array}{l}\text { Sequential decision making } \\
\text { under uncertainty }\end{array}$ & High-damage and low-damage scenarios \\
\hline ICAM-2 & Simulation & Propagation of uncertainty & $\begin{array}{l}\text { Parameters (up to } 25 \text { ); } \\
\text { Decision rules and metrics; } \\
\text { Model structure }\end{array}$ \\
\hline PAGE & Simulation & $\begin{array}{l}\text { Propagate uncertainty } \\
\text { about input parameters } \\
\text { through model; } \\
\text { Partial rank coefficients } \\
\text { between inputs and outputs }\end{array}$ & $\begin{array}{l}80 \text { uncertain parameters; } \\
\text { Costs of control; } \\
\text { Costs of adaptation; } \\
\text { Valuation of impacts }\end{array}$ \\
\hline
\end{tabular}

Sources: Adapted from [19, 67].

\subsection{Equity across time and space}

The impact of climate change and greenhouse gases abatement will last for centuries or even millennia in the future. Therefore, there is a welfare tradeoff between the current generation and future generations, which is a question of intergenerational equity. On the other hand, combating climate change needs all countries' cooperation, so there is a problem of assessing the impact from climate change upon different countries and distributing responsibilities among different countries, namely interregional equity.

\subsubsection{Intergenerational equity}

Because climate change is a long-term problem, climate policy models which estimate welfare, income, or costs over many generations must somehow evaluate gains and losses from different time periods. In climate policy modeling, discount rate is the most commonly employed tool to measure the intergenerational equity. The early work of Frank Ramsey [68] provides the basis for this widely utilized approach, in which there are three parameters to determine discount rate $(r)$ : the rate of pure time preference $(\rho)$, the elasticity of marginal utility $(\eta)$ and the growth rate of consumption per capita ( $g$ ) (see formula (1)).

$$
r=\rho+\eta g .
$$

The rate of pure time preference $(\rho)$ is the rate at which the welfare of future generations is discounted to the present without taking resources and opportunities which may be obtained by the future society into account. It is calculated in percent per unit time. The higher the rate of pure time preference, the less we value damage to future generations from climate change and the less we value benefits that future generations obtain by mitigating 
climate change. The important distinction between $\rho$ and $r$ is that $\rho$ is a more primitive rate of pure time preference that discounts utility, while $r$ is the much more familiar interest rate used to discount consumption [69]. The elasticity of marginal utility $(\eta)$ is the elasticity of marginal utility with respect to consumption per capita, which reflects the diminishing marginal utility of income over time as society becomes richer. The higher the elasticity of marginal utility, the more we value the poor's welfare. Under the assumption of positive growth rate of consumption per capita, future generations will be much richer than the current generation. Therefore, the higher the elasticity of marginal utility, the more we value the welfare of current generation. The growth rate of consumption per capita $(g)$ influences discount rate by its sign and value. If consumption per capita doesn't grow over time $(g=0)$, discount rate is equal to the rate of pure time preference. If consumption per capita grows over time $(g>0)$, discount rate is larger than the rate of pure time preference.

The value of the discount rate $(r)$ is critical to the results of climate policy models. A small change in the discount rate may cause a significant change in the model results which may cause completely opposite climate policy proposals. There arises a controversial debate over the value of the discount rate in climate policy modeling. Arrow et al. [70] divided researchers into two categories: prescriptionists and descriptionists. Prescriptionists emphasize the equity and value the discount rate from the standpoint of ethics, so they prefer to use a low or even zero rate of pure time preference $(\rho)$ and low elasticity of marginal utility $(\eta)$, which results in a low discount rate. Because a low discount rate leads to a high present value of costs of future generations, prescriptionists advocate taking immediate actions to mitigate GHG emissions dramatically. Stern Review [6], for example, chose a relatively low discount rate $(1.4 \%)$ in the PAGE model. The results estimated that actions needed to be taken immediately to keep GHG levels in the atmosphere stabilized between 450 and 550ppm $\mathrm{CO}_{2}$ equivalent. Otherwise, damage from climate change could be $20 \%$ of GDP or more.

Descriptionists who emphasize the efficiency argue that the discount rate should be based on consumer behavior and real return on capital. They use a relatively high rate of pure time preference $(\rho)$ and elasticity of marginal utility $(\eta)$, which results in a high discount rate. The high discount rate leads to a low present value of costs of future generations. 
Descriptionists advocate "step-by-step" actions in climate policies, which mean modest rates of emissions reduction in the near term, followed by sharp reduction in the medium and long term. Nordhaus [71], for example, chose a relatively high discount rate (around 5.5\%) in the DICE model. The results showed that atmospheric concentrations of $\mathrm{CO}_{2}$ would reach 685 ppm in 2100 (global surface temperature will increase by $3.1^{\circ} \mathrm{C}$ relative to 1990 ), and the damages associated with these temperature changes would be $3 \%$ of global output. In addition, global temperature would increase by $5.3^{\circ} \mathrm{C}$ in 2200 relative to 1990 , and the damages would be close to $8 \%$ of global output.

Most climate policy models consider the discount rate as an exogenous and constant value. Recently, some researchers argue that a dynamic discount rate should be utilized. Stern Review [6] insisted that the discount rate depended on the way in which consumption grew over time, so it was not constant over time. To be specific, if consumption fell along a path, the discount rate could be negative; if inequality rose over time or uncertainty rose, the discount rate would decrease. In the DICE-2007 model [71], the rate of pure time preference was $1.5 \%$, and the elasticity of marginal utility was 2 . The growth rate of consumption per capita was $1.6 \%$ per year in 2005 , decreasing to $1 \%$ in 2405 . Therefore, the discount rate for the DICE-2007 would decline from 4.7\% down to 3.5\% during 400 years. Table 6 demonstrates the discount rate and relative parameters of some representative researchers.

Table 6 Comparison of discount rates of some representative researchers.

\begin{tabular}{|c|c|c|c|c|c|c|c|}
\hline \multirow[b]{2}{*}{ Researcher } & \multicolumn{4}{|c|}{ Constant } & \multicolumn{3}{|c|}{ Dynamic } \\
\hline & Cline & Nordhaus & Stern & Edenhofer & Nordhaus & Weitzman & Gollier \\
\hline$\rho$ & 0 & $3 \%$ & $0.1 \%$ & $1 \%$ & $1.5 \%$ & 0 & $2 \%$ \\
\hline$\eta$ & 1.5 & 1 & 1 & $3.1 * *$ & 2 & 3 & 2 \\
\hline$g$ & $1.3 \% *$ & $1.3 \% *$ & $1.3 \%$ & $1.3 \% *$ & $1.6 \% \rightarrow 1 \%$ & $2 \%$ & $1.5 \%$ \\
\hline \multirow[t]{2}{*}{$r$} & $1.95 \% * *$ & $4.3 \% * *$ & $1.4 \%$ & $5 \%$ & $4.7 \% \rightarrow 3.5 \%$ & $6 \% \rightarrow$ & $5 \% \rightarrow$ \\
\hline & & & & & & Minimum & Minimum \\
\hline Reference & [72] & {$[63]$} & {$[6]$} & [73] & [71] & [74] & {$[75]$} \\
\hline
\end{tabular}

Note: This figure is adapted from [19, 76]. $\rho, \eta, g$ and $r$ represent the rate of pure time preference, elasticity of marginal utility, growth rate of consumption per capita, and discount rate, respectively. $*$ For researchers who don't directly state the value of $g$, we assume $g=1.3 \%$ according to the Stern Review. ** These values are calculated by authors based on the assumption that $g=1.3 \%$. " $\rightarrow$ " represents the value declines over time.

\subsubsection{Interregional equity}


Interregional equity is concerned with the issue of assessing the impact from climate change, and the issue of distributing abatement responsibilities among different regions [77]. In climate policy modeling, the key parameters characterizing interregional equity are the welfare weights of different regions [78]. At present, most climate policy models add equally weighted regional welfare to determine the global welfare. The optimal abatement targets are obtained by maximizing the global welfare. However, there is a "problem" with this approach. If identical, diminishing marginal returns to income in every region are assumed, the model can increase utility by moving income from the richer regions towards the poorer regions. This can be accomplished by allocating regionally specific damage and abatement costs, or by inducing transfers between regions for the purpose of fostering technical change, or funding adaptation, or by purchasing emission allowances, or by any other channel available in the model for inter-regional transfers [79].

In order to solve this "problem", some climate policy models have adopted the use of "Negishi weights" [80]. In the Negishi procedure, the marginal product of capital is equal in all regions and, therefore, no transfers are necessary to assuage the redistributive imperative of diminishing marginal returns. However, since the marginal product of capital is higher in poorer regions, the Negishi weights give greater importance to utility in richer areas. The unspoken implication is that human welfare is more valuable in richer parts of the world [81, 82]. Some climate policy models include both discounting over time and Negishi weights. These models accept the diminishing marginal utility of income for intergenerational choices, but reject the same principle in the contemporary and interregional context. This is obviously an inconsistent approach.

\subsection{Endogeneity of technological change}

Technological change (TC) is seen as one of major determinants of future global energy demand levels as well as the associated carbon dioxide emissions, and global climate impacts [83]. The appropriate treatment of technological change is one of the most complex and salient questions remaining in climate policy modeling. Nonetheless, most climate policy models treat technology as an exogenous variable-simply an autonomous function of time. Since policies adopted to combat climate change are likely to have great impact on the pace 
and direction of technological change, these models miss the important link between policy and innovation [84].

Exogenous technology change can be partitioned into two categories. One category treats technological change mainly as an exogenous process of cost and efficiency improvements of a relatively rich set of specific energy technologies. The other category treats technological change, capital and labor, sometimes explicitly complemented by energy or electricity as production factors of economic output. Technology is often included in these macroeconomic models as a separate coefficient in the production function, for example, as an overall productivity factor augmenting over time as an autonomous energy efficiency increase (AEEI). Examples of these models are MERGE [56], CETA [48], DICE [46], and RICE [47].

Recently, climate policy models begin to include technological change as an endogenous process. The three most commonly used approaches to model endogenous TC include direct price-induced, R\&D-induced and learning-induced. First, direct price-induced TC implies that changes in relative prices can spur innovation to reduce the use of the more expensive input (such as energy). In climate policy modeling, if the price of energy rises, direct price-induced TC will promote energy efficiency, often through a productivity parameter that is tied to prices or through earlier diffusion of energy-efficient technologies. In the ICAM model, for example, the expectation that the price of energy would rise induces technological change [85]. Second, research and development-induced TC allows for R\&D investment to influence the rate and direction of technological change. R\&D-induced TC is one of the most common approaches utilized to model TC, and a variety of models have been developed along these lines. There is considerable diversity in R\&D-based approaches that model TC, and model structure is the dominant factor in this further division. Different model structures tend to use different R\&D-induced TC (see Gillingham [86] to learn about more detailed introduction of R\&D-induced TC). Finally, learning-induced TC allows for the unit cost of a particular technology to be a decreasing function of the experience with a particular technology. Learning-by-doing (LBD) is the most commonly employed method in this approach, and the unit cost of this technology is typically modeled as a decreasing function of its cumulative output [86]. Table 7 shows the modeling approaches of technological change in some selected 
climate policy models.

As stated above, there have been several approaches that model endogenous technological change. For future research into endogenous technological change, climate policy modelers need to consider the following three questions: how to model increasing returns to scale; how much technological detail to model; and how to model macroeconomic feedback. First, many models, especially general equilibrium models, are based on the assumption that technologies are characterized by decreasing returns to scale in order to ensure only one, unique equilibrium result $[79,87]$. The assumption of decreasing returns to scale may be true for resource-based industries, but it is not appropriate for many knowledge-based industries. The field of mitigating climate change involves many knowledge-based industries. Therefore, modeling increasing returns to scale can make climate policy models to a more realistic portrayal of the structure and nature of emissions abatement and economic development options. Second, climate policy modelers have to make a choice of how much technological detail to include in the model. In other words, how many regions, industries, fuels, abatement technologies, or end uses to include in a model [79]. A more detailed technology sector can improve model accuracy but there are limits on the returns from adding detail - at some point, data requirements, spurious precision, and loss of transparency begin to detract from a model's usefulness. Finally, the third choice is how to model macroeconomic feedback from abatement to economic productivity. A common approach is to treat abatement costs as a pure loss of income, such as DICE [46] and RICE [47]. Two concerns to this approach seem to be particularly important. If abatement costs are modeled as a dead-weight loss, it means that all money spent on abatement is wasted, and this diminishes human welfare. However, many costs of abatement can provide jobs or otherwise raise income, and can build newer, more efficient capital. A related issue is the decision to model abatement costs as losses to income. Abatement costs more closely resemble additions to capital, rather than subtractions from income [79].

Table 7 Approaches of technological change in selected climate policy models.

\begin{tabular}{llll}
\hline Approach of technological change & Model & Model type & Reference \\
\hline Exogenous & DICE & Optimization & {$[46]$} \\
\hline
\end{tabular}




\begin{tabular}{llll}
\hline RICE & Optimization & {$[47]$} \\
GREEN & CGE & {$[88]$} \\
SGM & CGE & {$[89]$} \\
& CEEPA & CGE & {$[87]$} \\
\hline ETC-RICE & Optimization & {$[90]$} \\
R\&D-induced & R\&DICE & Optimization & {$[91]$} \\
& ENTICE & Optimization & {$[84]$} \\
\hline \multirow{2}{*}{ Learning-induced } & GET-LFL & Optimization & {$[92]$} \\
& FEEM-RICE & Optimization & {$[93]$} \\
\hline Direct price-induced & ICAM-3 & Simulation & {$[85]$} \\
\hline IMAGE & Simulation & {$[94]$} \\
\hline
\end{tabular}

Source: Adapted from [19, 86].

\subsection{Greenhouse gases abatement mechanism}

It has been widely accepted that we need to reduce GHG emission to mitigate climate change, but there is still controversy about the abatement mechanism. In the literature, abatement mechanisms can be divided into three categories: command-and-control mechanism, quantity-based mechanism, and price-based mechanism [95-98].

The command-and-control mechanism means that the government utilizes administrative measures to reduce GHG emission forcibly. This approach is frequently inefficient, so it is usually not recommended [98]. The controversy about the abatement mechanism in climate policy modeling mainly focuses on quantity-based mechanism and price-based mechanism. A quantity-based mechanism — usually referred to as a permit or cap-and-trade system — works by first giving participants (such as countries, industries and enterprises) a limit on emission permits, and then allowing them to buy or sell permits in the market [99-101]. Its advantage is that the reduction level can be controlled directly while the carbon price is uncertain [102]. One key element in the cap-and-trade system is that participants are free to buy and sell permits in order to obtain the lowest cost for themselves, which should lead to the lowest cost for society. In particular, participants who can reduce emission more cheaply will do so to sell excess permits. Conversely, participants who have higher reduction cost will avoid reductions 
by buying permits. In this way, total emissions will exactly equal the number of permits, and only the cheapest reductions will be undertaken [95]. A price-based mechanism- usually referred to as a carbon tax or emissions fee - requires the payment of a fixed fee for every ton of $\mathrm{CO}_{2}$ emitted [103]. In this way, the carbon price can be controlled directly, which will determine reduction level indirectly. Only those emitters who can reduce emissions at a cost below the fixed fee or tax will choose to do so, therefore, price-based mechanism is also cost-effective [95].

Researchers who focus on political and legal concerns favor quantity-based mechanism, but most researchers who use cost-benefit analysis argue that the price-based mechanism is more efficient. Seminal work by Weitzman [96] showed that a price-based mechanism was more efficient than a quantity-based mechanism if the slope of the marginal cost function was greater than the absolute value of the slope of the marginal benefit function, and a quantity-based mechanism dominated if the inequality was reversed. Nordhaus [98] utilized the RICE model to compare the pros and cons of the two mechanisms, focusing on such issues as performance under conditions of uncertainty, volatility of the induced carbon prices, the excess burden of taxation and regulation, transparency, and ease of implementation. The results revealed that the price-based mechanism was likely to be more effective and more efficient. Pizer [97] developed a stochastic computable general equilibrium model to simulate the two mechanisms. The results indicated that the expected welfare gain from the optimal price-based policy was five times higher than the expected gain from the optimal quantity-based policy, and consequently the price-based mechanism was more efficient.

Recently, some researches have proposed a hybrid mechanism which combines both a quantity-based mechanism and a price-based mechanism. Pizer [97] suggested an alternative hybrid policy, using an initial distribution of tradeable permits to set a quantitative target, but allowing additional permits to be purchased at a fixed "trigger" price. The results were based on a stochastic computable general equilibrium model, and demonstrated that hybrid policies offer dramatic efficiency improvements over quantity-based polices and price-based policies. Therefore, a hybrid policy was an attractive alternative to either a pure price or quantity system. Table 8 summarizes the definition, approach, feature, and example of four abatement mechanisms. 
Table 8 Comparison among four abatement mechanisms.

\begin{tabular}{|c|c|c|c|c|}
\hline Mechanism & Definition & Approach & Feature & Example \\
\hline $\begin{array}{l}\text { Command-and- } \\
\text { control }\end{array}$ & $\begin{array}{l}\text { Governments use } \\
\text { administrative means to } \\
\text { reduce GHG emission forcibly }\end{array}$ & Administrative means & $\begin{array}{l}\text { Quick effect } \\
\text { but inefficient }\end{array}$ & $\begin{array}{l}\text { Chinese government } \\
\text { closes down outdated } \\
\text { production facilities }\end{array}$ \\
\hline Quantity-based & $\begin{array}{l}\text { Giving participants a limit of } \\
\text { emission permits, and } \\
\text { allowing them to buy or sell } \\
\text { permits }\end{array}$ & Cap-and-trade & $\begin{array}{l}\text { Reduction } \\
\text { level can be } \\
\text { controlled } \\
\text { directly }\end{array}$ & $\begin{array}{l}\text { Kyoto Protocol; } \\
\text { EU ETS }\end{array}$ \\
\hline Price-based & $\begin{array}{l}\text { Requiring the payment of a } \\
\text { fixed fee for every ton of } \mathrm{CO}_{2} \\
\text { emitted }\end{array}$ & $\begin{array}{l}\text { Carbon tax or } \\
\text { emissions fee }\end{array}$ & $\begin{array}{l}\text { Carbon price } \\
\text { can be } \\
\text { controlled } \\
\text { directly }\end{array}$ & $\begin{array}{l}\text { Carbon emission tax } \\
\text { on airlines in } \\
\text { European Union }\end{array}$ \\
\hline Hybrid & $\begin{array}{l}\text { Combining both quantity } \\
\text { mechanism and price } \\
\text { mechanism }\end{array}$ & $\begin{array}{l}\text { Setting a quantitative } \\
\text { target, but allowing } \\
\text { the purchase of } \\
\text { permits from the } \\
\text { government at a fixed } \\
\text { price }\end{array}$ & $\begin{array}{l}\text { Efficiency is } \\
\text { dramatically } \\
\text { improved over } \\
\text { other } \\
\text { mechanisms }\end{array}$ & Pizer (2002) \\
\hline
\end{tabular}

Sources: Adapted from [19].

\subsection{Enterprise risk in climate policy models}

Current understanding of the natural and social sciences of climate change problem is still incomplete, and it is not possible to build climate policy models that contain all the elements, processes, and feedback mechanisms that are likely to be important. Therefore, there are potential risks that climate policy models cannot precisely assess the impacts of climate polices. Climate change risks are part of sustainability risks, which need to be incorporated into Enterprise Risk Management (ERM) system. The ERM is one of the most important issues in business management $[104,105]$.

Climate policy models usually contain climate modules and economic modules which both create risks. Firstly, the main source of risk in climate modules is the omission of potentially key factors or effects, including thawing of the permafrost and release of methane, collapse of land-based polar ice sheets, release of sea-bed methane, and complex interaction with ecosystems and biodiversity more generally [106]. Secondly, it creates risks that many 
sensitive parameters are set as fixed values in economic modules. Pindyck [107] stated that certain inputs in climate policy models were arbitrary, but had huge effects on the results; the models could not tell us the possibility of a catastrophic climate outcome. Therefore, these models' results were illusory and misleading. Stern [106] considered that climate policy models underestimated the risk, because they omitted key factors that were hard to capture precisely, and assumed directly that the impacts and costs would be modest. It was vital that climate policy analysis was treated as a risk-management problem.

One common method to assess the risk in climate change is to replace fixed values with random variables. Mastrandrea and Schneider [108] assessed the risk of climate change used a probabilistic integrated assessment model. In the model, three key parameters were set as random variables, including climate sensitivity, climate damages, and discount rate. The results showed that under midrange assumptions, optimal climate policy controls could reduce the probability of dangerous anthropogenic interference from $45 \%$ under minimal controls to near zero. Weitzman [59] stated that there was deep fat-tailed uncertainty in the economics of catastrophic climate change, which induced a "fat tails" in the probability distributions. Therefore, standard approaches to modeling the economics of climate change very likely failed to account the risk of climate change.

Many climate policies are introduced through a price mechanism, such as permit trading scheme and carbon tax, the current and potential future cost of emissions will increase enterprises' risks. Yang et al. [109] used a real options model for analyzing the effects of government climate policy on investment risks in the power sector. The results revealed that climate change policy risks could become large if there was only a short time between a future climate policy and the time when the investment decision is being made. In addition, the government would be able to reduce investors' risks by implementing long-term rather than short-term climate change policy frameworks.

\section{Methodologies in climate policy modeling research}

Based on the results of keywords frequency, we summarize twelve types of models. The three most widely used climate policy models are optimization models, computable general equilibrium (CGE) models, and simulation models. Fig. 6 and Fig. 7 demonstrate the trends 
of all types of models between 1991 and 2013.

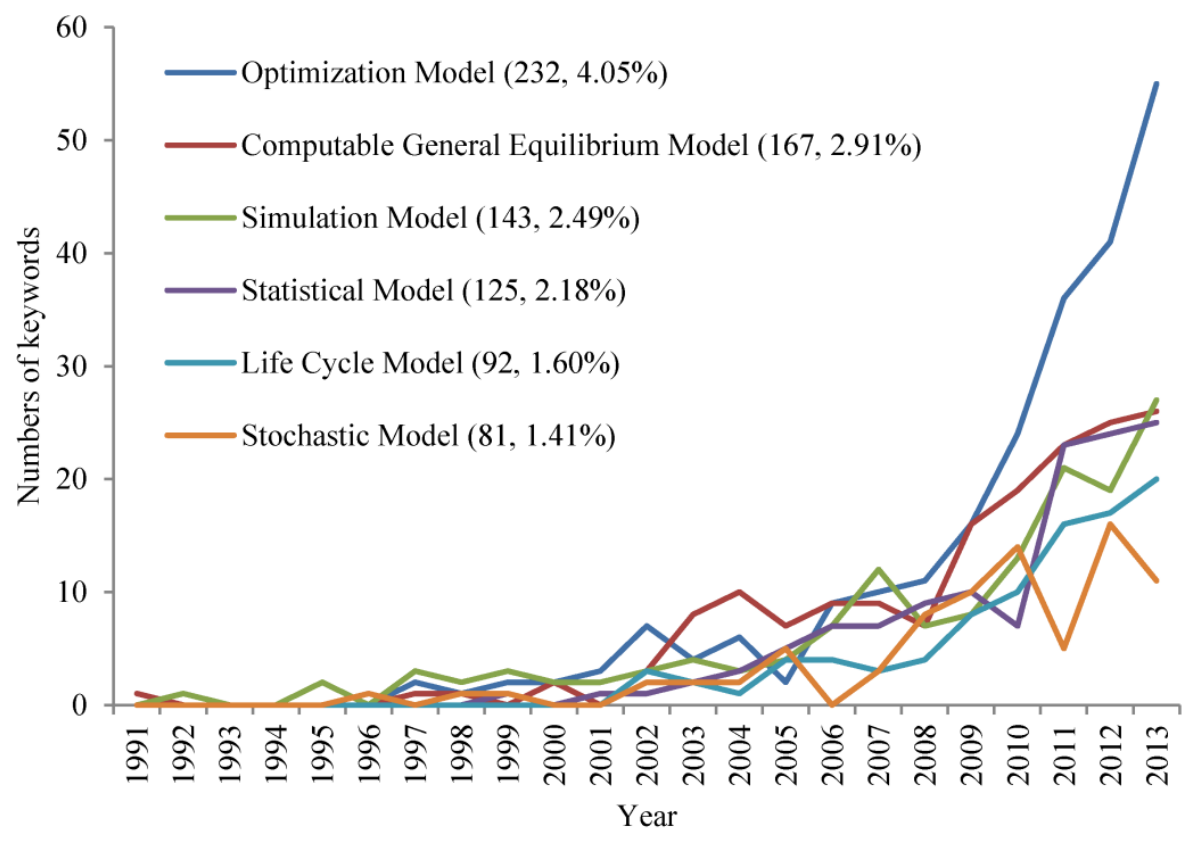

Fig. 6. Methodologies of climate policy modeling (1).

Note: This figure is adapted from [30]. The figures in parentheses refer to the cumulated numbers of keywords to the corresponding model types and their proportions in all publications.

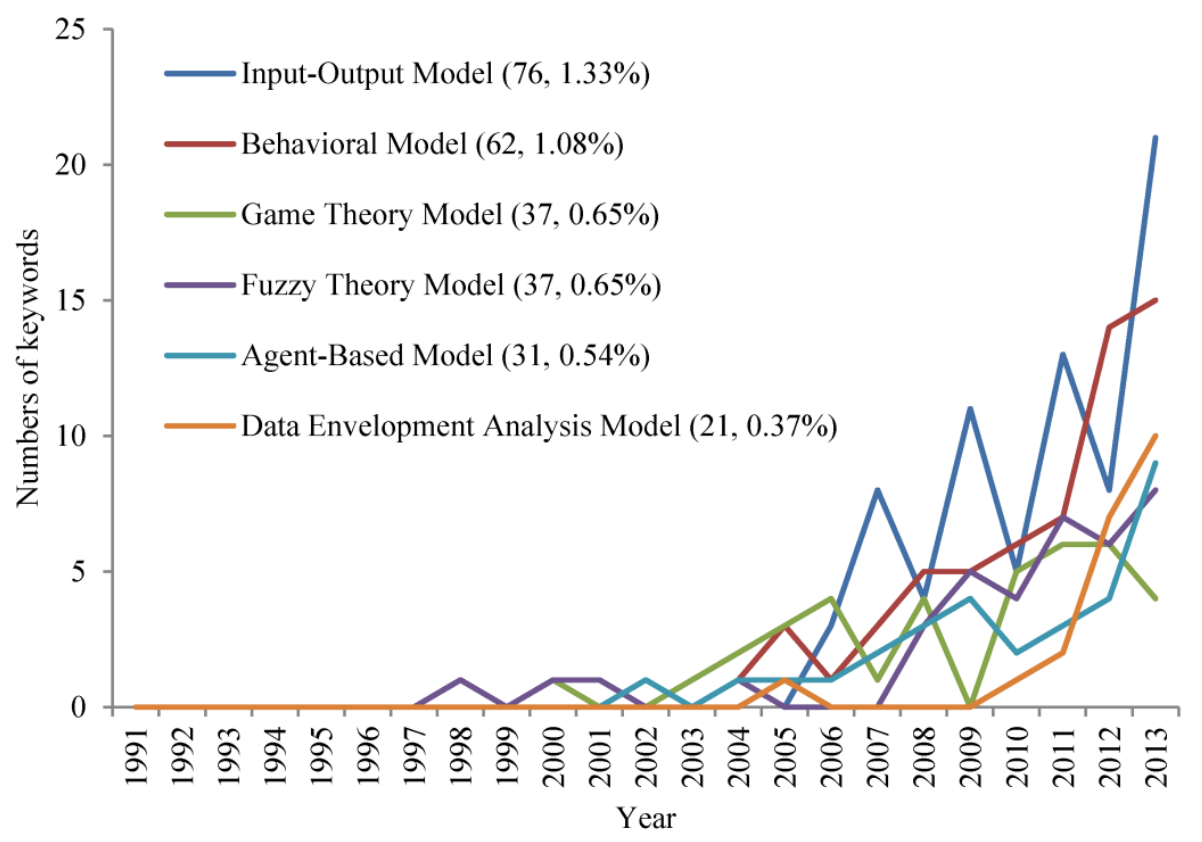

Fig. 7. Methodologies of climate policy modeling (2).

Note: This figure is adapted from [30]. The figures in parentheses refer to the cumulated numbers of keywords to the corresponding model types and their proportions in all publications. 


\subsection{Optimization models}

Climate policies involve numerous optimization problems, such as GHG emission reduction targets [110-112], GHG abatement paths [113-115], allocation of GHG permits [116-118], GHG abatement costs [119, 120], carbon taxes [121, 122], and carbon prices [123, 124]. Consequently, optimization models are widely used in climate policy modeling.

The objective function is a key element in optimization models [125, 126], and various modelers normally choose different objective functions (see Table 9). Optimization models can be divided into two categories based on their objective functions: welfare maximization and cost minimization. The basic principle of the welfare optimization models is that production causes both emissions and consumption. Emissions affect the climate, thereby causing damage that reduces production. The models maximize the discounted present value of welfare across all time periods by choosing how much emission to abate in each time period, where abatement costs reduce production. In these models, the consumption returns to welfare are always positive but diminish as people grow wealthier. DICE [46], RICE [47] and FUND [127] are both optimization models. A key component in optimization models is the welfare function. A popular choice is to define individual welfare as the logarithm of per capita consumption or income,

$$
\begin{aligned}
& u=\log (C / L), \\
& U=L \times u=L \times \log (C / L),
\end{aligned}
$$

where $u$ is individual welfare, $C$ is total social consumption, $L$ is total population, and $U$ is total social welfare.

Cost minimization models are designed to identify the most cost-effective solution to a climate policy model. Some cost minimization models explicitly include a climate module, while others use the emissions to represent climatic change and damages. GET-LFL [92] is an example of a cost minimization model.

As shown in Fig. 6, optimization models have developed rapidly after 2005, and have become the most commonly utilized model from 2010 to 2013. Optimization models are likely to continue this tendency of rapid development. 
Table 9 Objective functions of selected optimization models.

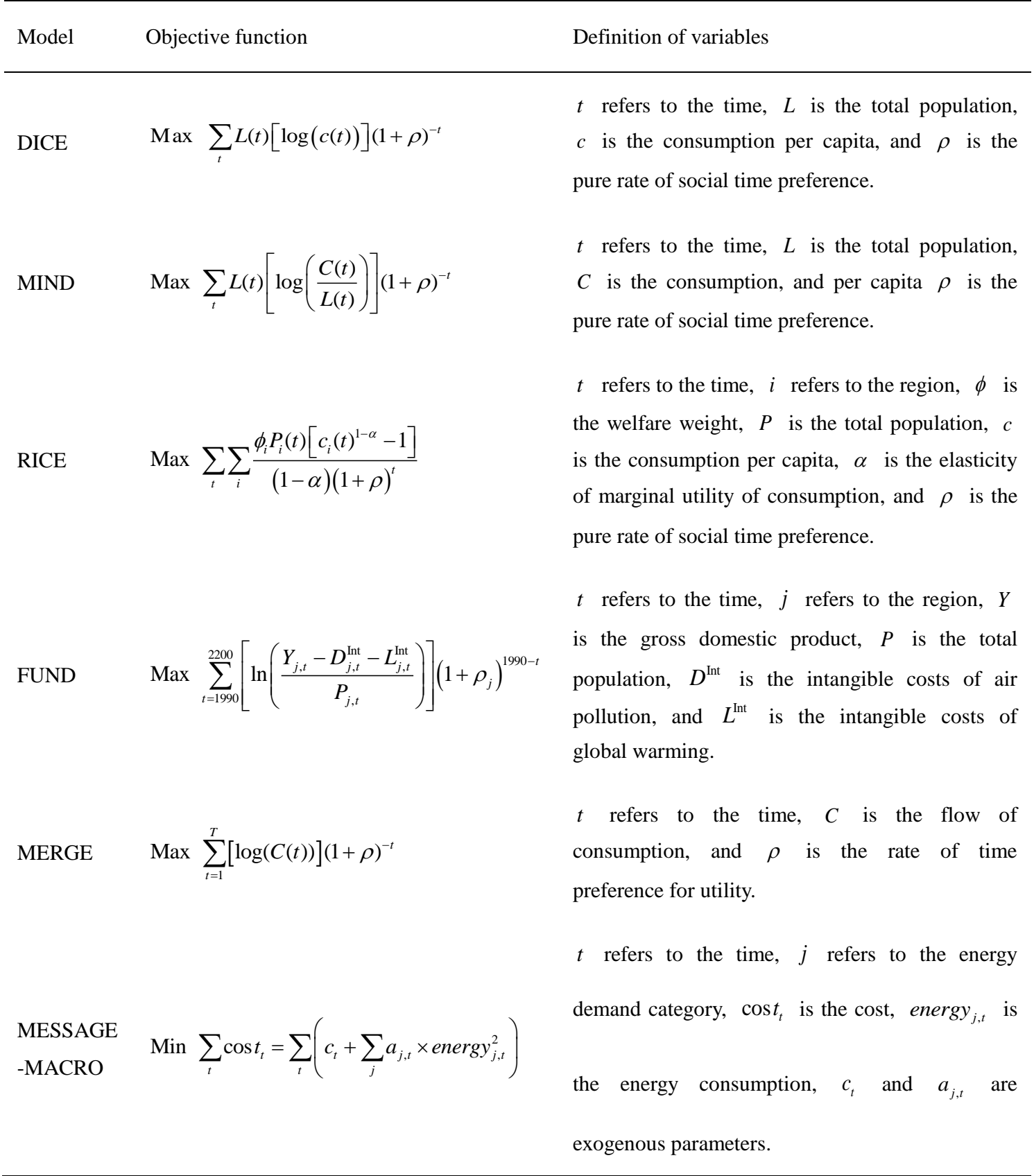

Note: See Table 10 to find the references of these models.

\subsection{CGE models}

Computable general equilibrium (CGE) models combine the abstract general equilibrium structure formalized by Arrow and Debreu with realistic economic data in order to numerically solve for the levels of supply, demand and price that support equilibrium across a specified set of markets. CGE models are a standard tool of empirical analysis, and are widely utilized to analyze the aggregate welfare and distributional impact of policies. The effects of these policies may be transmitted through multiple markets, or contain menus of different tax, 
subsidy, quota or transfer instruments [128]. CGE models can describe the interactions between different markets, and estimate the direct and indirect impact of climate policies. These characteristics cause CGE models to be frequently used in climate policy assessment [129].

The foundations of CGE models are the circular flow of commodities in a closed economy and Walrasian general equilibrium (see Fig. 8). The main actors in Fig. 8 are households, firms, and government. The households own the factors of production and are the final consumers of produced commodities. The firms rent the factors of production from the households for the purpose of producing goods and services that the households then consume. The role of the government is to collect taxes and disburse these revenues to firms and households as subsidies and lump-sum transfers, subject to rules of budgetary balance that are specified by the analyst [128]. There are two equilibriums in the economic flows in Fig. 8: conservation of product and conservation of value. To be specific, conservation of product reflects the physical principle of material balance, while conservation of value reflects the accounting principle of budgetary balance [128].

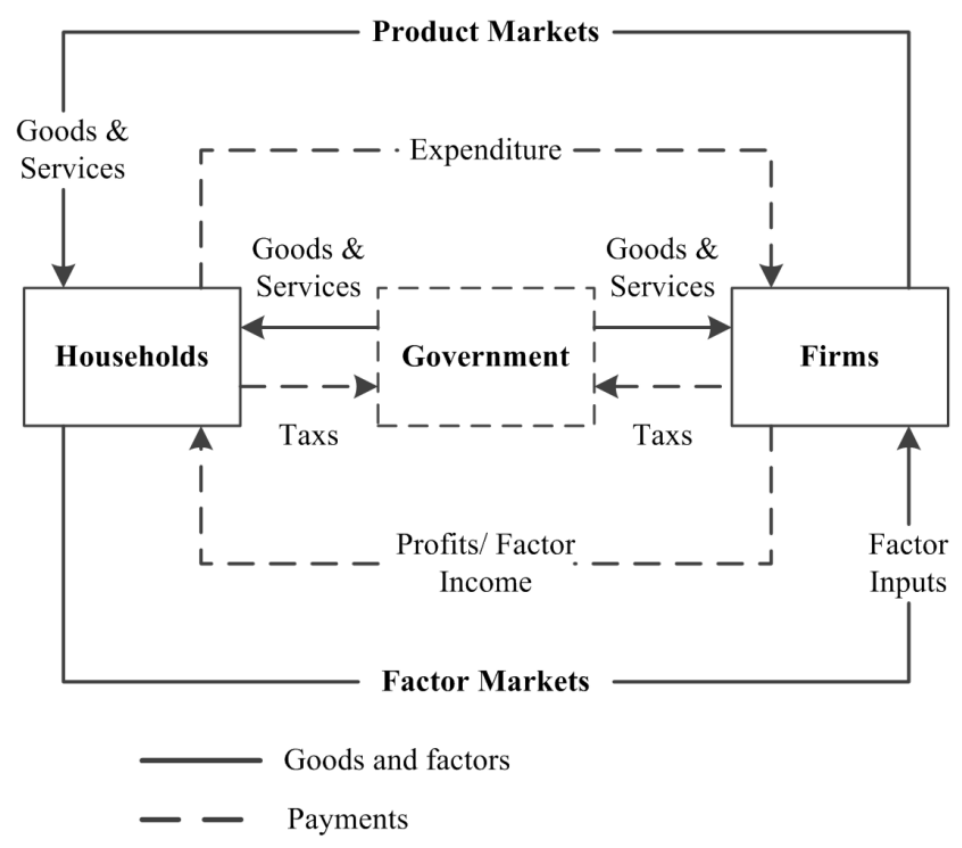

Fig. 8. The framework of CGE models.

CGE models used in climate policy research usually focus on the following issues: costs of emission abatement and the carbon tax level to achieve a certain abatement target; social 
costs of different use patterns of carbon tax; climate policy's impacts on the income distribution, employment, and international trade; relationships between GHG emission abatement and traditional pollutants control; comparison between quantity-based abatement policy and price-based abatement policy[87, 128, 130, 131]. According to our database, the first article about CGE models was published in 1991. Sheron et al. [132] employed a CGE model to analyze the impact of crop losses due to a global climate change or environmental event on the U. S. economy.

As shown in Fig. 6, there were two rapid development phases for CGE models: 2001-2004 and 2008-2013. Especially, during the second phase, the number of articles about CGE models increased dramatically from seven in 2008 to twenty-six in 2013, but the growth rate slowed down.

\subsection{Simulation models}

Simulation models are based on off-line predictions about future emissions and climate conditions. These models are characterized by exogenous parameters that determine the amount of carbon which can be used in production. Therefore climate outcomes are not affected by the economic module. Simulation models cannot answer questions of what policy makers should do to maximize social welfare or minimize social costs. Instead, the simulation models estimate the costs of various likely future emission paths [79].

Climate policy assessment involves natural science, such as environmental science, meteorology and atmospheric science, and ecology, and consequently modelers need to simulate physical processes. On the other hand, climate change is a long-term problem, so future GHG emissions and economic development scenarios need to be simulated in climate policy models. Therefore, simulation models are also an important approach in climate policy modeling. According to our database, the first article involving simulation models was published in 1992. Din [133] combined Geographic Information Systems (GIS) with techniques from dynamic simulation and expert systems. This approach created dedicated decision support systems which provided an interactive approach to informing decision makers and the general public. It also provided a practical management tool for implementing strategies for responses to global environmental change. Table 10 demonstrates selected 
existing optimization models, CGE models and simulation models.

Table 10 Selected models of optimization models, CGE models and simulation models.

\begin{tabular}{clll}
\hline & Optimization & CGE & Simulation \\
\hline DICE [46] & JAM [134] & \\
ENTICE [84] & IGEM [135] & \\
& MIND [73] & & \\
& GET-LFL [92] & & \\
\hline & RICE [47] & GTAP-E [141] & PAGE [146] \\
& FUND [127] & MIT-EPPA [142] & ICAM-1 \\
& CETA [48] & CEEPA [87] & IMAGE [94] \\
& MERGE [56] & AIM [143] & GIM [148] \\
& GRAPE [136] & GREEN [88] & \\
PRICE [137] & GLOBAL2100 [144] & \\
& FEEM-RICE [93] & SGM [89] & \\
& DNE21+ [138] & WIAGEM [145] & \\
& MESSAGE-MACRO [139] & & \\
& ECLIPSE [140] & & \\
\hline
\end{tabular}

Sources: Adapted from [19].

\subsection{Other models}

As shown in Fig. 7, behavioral models and data envelopment analysis (DEA) models were introduced into climate policy assessment in recent years and their application was rapidly increased. The number of articles that pertain to behavioral models increased from one in 2006 to fifteen in 2013. The first article utilizing DEA models appeared in 2010, and ten additional articles occurred in 2013.

\section{Concluding remarks}

According to the bibliometric analysis of climate policy modeling, we have obtained the following conclusions.

(1) An analysis of the basic characteristics of climate policy modeling indicates that climate policy modeling is an interdisciplinary area because three hundred and thirty-two subject categories are involved in this area. They can be divided into several disciplines, including environmental sciences, economics, geosciences, meteorology \& atmospheric sciences, ecology, management sciences, and others. Climate policy modeling has entered a 
phase of rapid development. The quantity of publications in this field has experienced the average annual growth rate of $26.71 \%$ during the period of 2001-2013.

(2) Based on the results of keyword frequency, the six most interesting research topics of climate policy modeling are integrated assessment of climate policies, uncertainty in climate change, equity across time and space, endogeneity of technological change, greenhouse gases abatement mechanism, and enterprise risk in climate policy models.

First, the integrated assessment model (IAM) which integrates natural science and social science is the most popular analysis framework in climate policy assessment. Most IAMs which have an abatement function and a damage function are based on the cost-benefit analysis. They determine the optimal path for controlling GHGs by maximizing the discounted present value of welfare.

Second, uncertainty in cost and benefits of climate policy creates a great challenge for climate policy models which are based on cost-benefit analysis (CBA). In order to deal with uncertainty in climate change, climate policy models in the future will need to answer the following questions: the appropriate probability distribution of the effects of climate change, the degree to which human society is risk averse, and the rate at which human society discounts future benefits and costs relative to those in the present.

Third, in climate policy models, the discount rate is the most commonly utilized tool to model intergenerational equity. Prescriptionists argue for the use of a low discount rate, and want to take immediate actions to dramatically mitigate GHG emissions. However, descriptionists argue for the use of high discount rate, and support "step-by-step" actions. Recently, some researchers believe that a dynamic discount rate which decreases to the minimum over time should be incorporated into the model. For interregional equity, welfare weights of different regions are the key element and need to be chosen reasonably in order to embody interregional fairness.

Fourth, including technological change as an endogenous process is a trend in climate policy modeling. The three most commonly employed approaches that model endogenous TC are direct price-induced, $R \& D$-induced and learning-induced.

Fifth, for the greenhouse gases abatement mechanism, researchers who focus on political 
and legal concerns prefer quantity-based mechanism, but most researchers who use cost-benefit analysis argue that a price-based mechanism is more efficient. Recently, several research papers have suggested that hybrid mechanism which combines both quantity-based mechanism and price-based mechanism can offer dramatic efficiency improvements.

Finally, one common method to assess the risk in climate change is to replace fixed values with random variables. Recent research states that there is deep fat-tailed uncertainty in the economics of catastrophic climate change, which induce a "fat tails" in the probability distributions. Therefore, standard approaches to modeling the economics of climate change very likely fail to account the risk of climate change. Many climate policies are introduced through a price mechanism, the current and potential future cost of emissions will increase enterprises' risks.

(3) Based on the results of keyword frequency, twelve types of models have been summarized. The three most frequently studied climate policy models are optimization models, computable general equilibrium (CGE) models, and simulation models. First, optimization models can be divided into two categories based on their objective functions: welfare maximization and cost minimization. Second, CGE models can describe the interactions between different markets, and estimate the direct and indirect impacts of climate policies, which encourages the frequent use of this model in climate policy assessment. Third, simulation models use exogenous parameters to determine the amount of carbon which can be used in production, and consequently climate outcomes are not affected by the economic module. Simulation models can estimate the costs of various likely future emission paths.

(4) Despite its rapid growth, climate policy modeling is at an early stage of development, and many challenges remain to be addressed. Several suggestions pertaining to climate policy modeling are as follows.

First, climate policy models need to be more transparent.

Because climate change is a large and complex problem, climate policy models are usually complicated and comprised of many sub-models adopted from a wide range of disciplines. These models are "black box" to decision makers and other citizens. Several 
practices might be helpful to increase transparency and reduce misunderstanding: 1) Specify clearly all assumptions, especially for those value-laden components; 2) Note components of the models which are highly sensitive, especially for those controversial problems; 3) Provide as many menu options as practical, especially for those choices which deal with culturally-dependent components [150]; 4) Make functions and program codes of models available to all readers.

Second, climate policy models need to meet policy maker needs.

The motivation of climate policy models is to assess the impact of climate policies and offer suggestions to policy makers. Policy modelers need to study the decision making of policy makers, and make policy models realistic and practical enough. Policy makers need to be convinced of the value of climate policy models as an indispensible tool in support of better informed future decisions.

Third, climate policy models need to utilize large-scale computer systems.

In an ideal world, where computers are infinitely fast and cheap, climate policy models would incorporate the most detailed available representations of each element of the climate problem. To date, however, this is unrealistic. Climate policy models should make full use large-scale computer systems to try to capture the main features of the climate problem.

Fourth, climate policy models need to involve subjective expert judgment about poorly understood factors that impact climate change.

Current understanding of the natural and social sciences of climate change problem is still incomplete, and currently it is not possible to build traditional analytical models that contain all the elements, processes, and feedback mechanisms that are likely to be important. Therefore, the policy discussion has often focused on what we know, rather than what is important. To avoid this difficulty in the climate change problem, it will be necessary to develop a new class of hybrid policy models which allows for an integration of subjective expert judgment about poorly understood parts of the problem with formal analytical treatments of the well-understood parts of the problem [10]. 


\section{Acknowledgements}

The authors gratefully acknowledge the financial support from the National Natural Science Foundation of China (NSFC) under the Grant No. 71020107026, National Basic Research Program of China under the Grant No. 2012CB955704, and Strategic Priority Research Program of the Chinese Academy of Sciences No. XDA05150600. We are also grateful to Professor Zili Yang and colleagues from CEEP-BIT for helpful suggestions that improved this paper.

Appendix A Introduction of several climate policy models discussed in this paper.

\begin{tabular}{|c|c|c|c|c|c|}
\hline Model & Full name & Authors & Institute & Model type & Reference \\
\hline DICE & $\begin{array}{l}\text { Dynamic Integrated Model } \\
\text { of Climate and the } \\
\text { Economy }\end{array}$ & $\begin{array}{l}\text { William D. } \\
\text { Nordhaus }\end{array}$ & Yale University, USA & Optimization & [46] \\
\hline RICE & $\begin{array}{l}\text { Regional Integrated Model } \\
\text { of Climate and the } \\
\text { Economy }\end{array}$ & $\begin{array}{l}\text { William D. } \\
\text { Nordhaus, Zili } \\
\text { Yang }\end{array}$ & Yale University, USA & Optimization & [47] \\
\hline FUND & $\begin{array}{l}\text { The Climate Framework for } \\
\text { Uncertainty, Negotiation } \\
\text { and Distribution }\end{array}$ & Richard S. J. Tol & $\begin{array}{l}\text { Vrije Universiteit, } \\
\text { Netherlands }\end{array}$ & Optimization & [127] \\
\hline MERGE & $\begin{array}{l}\text { Model for Evaluating } \\
\text { Regional and Global Effects } \\
\text { of GHG Reduction Policies }\end{array}$ & $\begin{array}{l}\text { Alan Manne, } \\
\text { Robert } \\
\text { Mendelsohn, } \\
\text { Richard Richels }\end{array}$ & $\begin{array}{l}\text { Stanford University, } \\
\text { USA }\end{array}$ & Optimization & {$[56]$} \\
\hline CETA & $\begin{array}{l}\text { Carbon Emissions } \\
\text { Trajectory Assessment }\end{array}$ & $\begin{array}{l}\text { Stephen C. Peck, } \\
\text { Thomas J. } \\
\text { Teiberg }\end{array}$ & $\begin{array}{l}\text { Electric Power } \\
\text { Research Institute, } \\
\text { USA }\end{array}$ & Optimization & {$[48]$} \\
\hline GTAP-E & $\begin{array}{l}\text { Energy-environmental } \\
\text { Version of the GTAP Model }\end{array}$ & $\begin{array}{l}\text { Jean-Marc } \\
\text { Burniaux, } \\
\text { Truong P. Truong }\end{array}$ & $\begin{array}{l}\text { Purdue University, } \\
\text { USA }\end{array}$ & CGE & {$[141]$} \\
\hline CEEPA & $\begin{array}{l}\text { China Energy and } \\
\text { Environmental Policy } \\
\text { Analysis }\end{array}$ & $\begin{array}{l}\text { Qiao-Mei Liang, } \\
\text { Yi-Ming Wei }\end{array}$ & $\begin{array}{l}\text { Beijing Institute of } \\
\text { Technology, China }\end{array}$ & CGE & [87] \\
\hline PAGE & $\begin{array}{l}\text { Policy Analysis of the } \\
\text { Greenhouse Effect }\end{array}$ & $\begin{array}{l}\text { Chris Hope, } \\
\text { John Anderson, } \\
\text { Paul Wenman }\end{array}$ & $\begin{array}{l}\text { University of } \\
\text { Cambridge, UK }\end{array}$ & Simulation & {$[146]$} \\
\hline ICAM-1 & $\begin{array}{l}\text { Integrated Climate } \\
\text { Assessment Model, Version } \\
1\end{array}$ & $\begin{array}{l}\text { Hadi } \\
\text { Dowlatabadi, M. } \\
\text { Granger Morgan }\end{array}$ & $\begin{array}{l}\text { Carnegie Mellon, } \\
\text { USA }\end{array}$ & Simulation & [147] \\
\hline IMAGE & Integrated Model for the & Jan Rotmans & National Institute of & Simulation & [94] \\
\hline
\end{tabular}




\begin{tabular}{ll}
\hline Assessment of the & Public Health and \\
Greenhouse Effect & Environmental \\
& Protection, \\
& Netherlands \\
\hline
\end{tabular}

Note: The institute is the first author's institute.

\section{References}

[1] Watson RT. Climate change: The political situation. Science. 2003;302:1925-1926.

[2] Jira C, Toffel MW. Engaging supply chains in climate change. Manufacturing \& Service Operations Management. 2013;15:559-577.

[3] Walther G-R, Post E, Convey P, Menzel A, Parmesan C, Beebee TJ, et al. Ecological responses to recent climate change. Nature. 2002;416:389-395.

[4] Kumar A, Jain V, Kumar S. A comprehensive environment friendly approach for supplier selection. Omega. 2014;42:109-123.

[5] Plambeck EL, Hope C. PAGE95: An updated valuation of the impacts of global warming. Energy Policy. 1996;24:783-793.

[6] Stern N. The economics of climate change: The Stern review. Cambridge, Uk: Cambridge University Press; 2007.

[7] IPCC. Climate Change 2014: Mitigation of Climate Change. Contribution of Working Group III to the Fifth Assessment Report of the Intergovernmental Panel on Climate Change. Cambridge, UK: Cambridge University Press; 2014.

[8] Murphy JM, Sexton DMH, Barnett DN, Jones GS, Webb MJ, Stainforth DA. Quantification of modelling uncertainties in a large ensemble of climate change simulations. Nature. 2004;430:768-772.

[9] Stocker TF. Climate change: Models change their tune. Nature. 2004;430:737-738.

[10] Dowlatabadi H, Morgan MG. Integrated assessment of climate change. Science. 1993;259:1813-1814.

[11] Kerr RA. Global change: Research Council says US climate models can't keep up. Science. 1999;283:766-767.

[12] Hu Z, Cao J, Hong LJ. Robust simulation of global warming policies using the DICE model. Management Science. 2012;58:2190-2206.

[13] Carmona R, Hinz J. Risk-neutral models for emission allowance prices and option valuation. Management Science. 2011;57:1453-1468.

[14] Sueyoshi T, Goto M. Returns to scale vs. damages to scale in data envelopment analysis: An impact of U.S. clean air act on coal-fired power plants. Omega. 2013;41:164-175.

[15] Chen S-G. Bayesian approach for optimal PV system sizing under climate change. Omega. 2013;41:176-185.

[16] Dowlatabadi H. Integrated assessment models of climate change: An incomplete overview. Energy Policy. 1995;23:289-296.

[17] Sen T, Hu X, Jiang K. Development of climate change integrated assessment models. Energy of China. 1997;12:9-14 (In Chinese).

[18] Wang C, Chen J, Zou J. Discussion on methematical model in climate policy study. 
Shanghai Environmental Sciences. 2002;7:435-439+454-458 (In Chinese).

[19] Wei Y-M, Mi Z-F, Zhang H. Progress of integrated assessment models for climate policy. Systems Engineering - Theory \& Practice. 2013;33:1905-1915 (In Chinese).

[20] Ramos-Rodríguez A-R, Ruíz-Navarro J. Changes in the intellectual structure of strategic management research: A bibliometric study of the Strategic Management Journal, 1980-2000. Strategic Management Journal. 2004;25:981-1004.

[21] Nederhof AJ. Bibliometric monitoring of research performance in the social sciences and the humanities: A review. Scientometrics. 2006;66:81-100.

[22] Meredith JR, Steward MD, Lewis BR. Knowledge dissemination in operations management: Published perceptions versus academic reality. Omega. 2011;39:435-446.

[23] Donohue JM, Fox JB. A multi-method evaluation of journals in the decision and management sciences by US academics. Omega. 2000;28:17-36.

[24] Brandenburg M, Govindan K, Sarkis J, Seuring S. Quantitative models for sustainable supply chain management: Developments and directions. European Journal of Operational Research. 2014;233:299-312.

[25] Wu DD, Olson DL. Computational simulation and risk analysis: An introduction of state of the art research. Mathematical and Computer Modelling. 2013;58:1581-1587.

[26] Holsapple CW, Lee-Post A. Behavior-based analysis of knowledge dissemination channels in operations management. Omega. 2010;38:167-178.

[27] Li J, Wang M-H, Ho Y-S. Trends in research on global climate change: A science citation index expanded-based analysis. Global and Planetary Change. 2011;77:13-20.

[28] Bjurstrom A, Polk M. Climate change and interdisciplinarity: A co-citation analysis of IPCC Third Assessment Report. Scientometrics. 2011;87:525-550.

[29] Hsu AW-h, Wang T. Does the market value corporate response to climate change? Omega. 2013;41:195-206.

[30] Wei Y-M, Mi Z-F, Zhang H. Review on climate policy modeling: An analysis based on bibliometrics method. Advances in Earth Science. 2013;28:930-938 (In Chinese).

[31] Idso SB. Shortcomings of $\mathrm{CO}_{2}$-climate models raise questions about the wisdom of energy policy implications. Applied Energy. 1984;16:53-57.

[32] Gucinski H, Lackey RT, Spence BC. Global climate change: Policy implications for fisheries. Fisheries. 1990;15:33-38.

[33] Mehos GJ, Ramirez WF. Use of optimal control theory to optimize carbon dioxide miscible-flooding enhanced oil recovery. Journal of Petroleum Science and Engineering. 1989;2:247-260.

[34] IPCC. Climate Change 2001: Mitigation. Contribution of Working Group III to the Third Assessment Report of the Intergovernmental Panel on Climate Change. Cambridge, UK: Cambridge University Press; 2001.

[35] Moss RH, Edmonds JA, Hibbard KA, Manning MR, Rose SK, van Vuuren DP, et al. The next generation of scenarios for climate change research and assessment. Nature. 2010;463:747-756.

[36] Lenton TM, Held H, Kriegler E, Hall JW, Lucht W, Rahmstorf S, et al. Tipping elements in the earth's climate system. Proceedings of the National Academy of Sciences of the United States of America. 2008;105:1786-1793.

[37] Katz RW, Brown BG. Extreme events in a changing climate: Variability is more 
important than averages. Climatic Change. 1992;21:289-302.

[38] Sallis JF, Bauman A, Pratt M. Environmental and policy: Interventions to promote physical activity. American Journal of Preventive Medicine. 1998;15:379-397.

[39] Giorgi F, Mearns LO. Approaches to the simulation of regional climate change: A review. Reviews of Geophysics. 1991;29:191-216.

[40] Alley RB, Marotzke J, Nordhaus WD, Overpeck JT, Peteet DM, Pielke RA, et al. Abrupt climate change. Science. 2003;299:2005-2010.

[41] Stern DI. The rise and fall of the environmental Kuznets curve. World Development. 2004;32:1419-1439.

[42] Unruh GC. Understanding carbon lock-in. Energy Policy. 2000;28:817-830.

[43] Duarte CM. The future of seagrass meadows. Environmental Conservation. 2002;29:192-206.

[44] Held IM, Soden BJ. Water vapor feedback and global warming. Annual Review of Energy and the Environment. 2000;25:441-475.

[45] Nordhaus WD. To slow or not to slow: The economics of the greenhouse effect. The Economic Journal. 1991;101:920-937.

[46] Nordhaus WD. The "DICE" Model: Background and structure of a dynamic integrated climate-economy model of the economics of global warming. Cowles Foundation Discussion Papers, Yale University; 1992.

[47] Nordhaus WD, Yang Z. A regional dynamic general-equilibrium model of alternative climate-change strategies. The American Economic Review. 1996;86:741-765.

[48] Peck SC, Teisberg TJ. CETA: A model for carbon emissions trajectory assessment. The Energy Journal. 1992;13:55-77.

[49] van Asselt MBA, Rotmans J. Uncertainty in integrated assessment modelling: From positivism to pluralism. Climatic Change. 2002;54:75-105.

[50] Hammitt JK. Outcome and value uncertainties in global-change policy. Climatic Change. 1995;30:125-145.

[51] Harvey LD. Development of a risk-hedging $\mathrm{CO}_{2}$-emission policy, part I: Risks of unrestrained emissions. Climatic Change. 1996;34:1-40.

[52] Paté-Cornell E. Uncertainties in global climate change estimates. Climatic Change. 1996;33:145-149.

[53] Schimmelpfennig D. Uncertainty in economic models of climate-change impacts. Climatic Change. 1996;33:213-234.

[54] Morgan MG, Keith DW. Subjective judgments by climate experts. Environmental Science \& Technology. 1995;29:468A-476A.

[55] Nordhaus WD. Expert opinion on climatic change. American Scientist. 1994;82:45-51.

[56] Manne A, Mendelsohn R, Richels R. MERGE: A model for evaluating regional and global effects of GHG reduction policies. Energy Policy. 1995;23:17-34.

[57] Stern N. The economics of climate change. The American Economic Review. 2008;98:1-37.

[58] Weitzman ML. Additive damages, fat-tailed climate dynamics, and uncertain discounting. In: Libecap GD, Steckel RH, editors. The economics of climate change: Adaptations past and present. Chicago, IL: University of Chicago Press; 2011. p. 23-46.

[59] Weitzman ML. On modeling and interpreting the economics of catastrophic climate 
change. The Review of Economics and Statistics. 2009;91:1-19.

[60] Anthoff D, Tol RS. Climate policy under fat-tailed risk: An application of fund. Annals of Operations Research. 2013;220:223-237.

[61] Heal G, Kristrom B. Uncertainty and climate change. Environmental \& Resource Economics. 2002;22:3-39.

[62] Peck SC, Teisberg TJ. Global warming uncertainties and the value of information: An analysis using CETA. Resource and Energy Economics. 1993;15:71-97.

[63] Nordhaus WD. Managing the global commons: The economics of climate change. Cambridge, MA: MIT Press; 1994.

[64] Tol RSJ. A decision-analytic treatise of the enhanced Greenhouse effect. Amsterdam, The Netherlands: Vrije Universiteit; 1997.

[65] Manne A, Richels R. The Greenhouse debate: Economic efficiency, burden sharing and hedging strategies. The Energy Journal. 1995;16:1-38.

[66] Dowlatabadi H, Ball M, Morgan MG, Patwardhan A, Kandlikar M, Sbevliakova E. An overview of the integrated climate assessment model version 2 (ICAM-2). In: Western Economic Association Conference, Vancouver, BC; 1994.

[67] Kann A, Weyant JP. Approaches for performing uncertainty analysis in large-scale energy/economic policy models. Environmental Modeling \& Assessment. 2000;5:29-46.

[68] Ramsey FP. A mathematical theory of saving. The Economic Journal. 1928;38:543-559.

[69] Weitzman ML. A review of the Stern Review on the economics of climate change. Journal of Economic Literature. 2007;45:703-724.

[70] Arrow KJ, Cline W, Maler K, Munasinghe M, Squitieri R, Stiglitz J. Intertemporal equity, discounting, and economic efficiency. Cambridge, UK: Cambridge University Press; 1996.

[71] Nordhaus WD. A question of balance: Weighing the options on global warming policies. New Haven, CT: Yale University Press; 2008.

[72] Cline WR. The economics of global warming. Washington, DC: Peterson Institute Press; 1992.

[73] Edenhofer O, Lessmann K, Bauer N. Mitigation strategies and costs of climate protection: The effects of ETC in the hybrid model mind. The Energy Journal. 2006;27:207-222.

[74] Weitzman ML. Risk-adjusted gamma discounting. Journal of Environmental Economics and Management. 2010;60:1-13.

[75] Gollier C. Expected net present value, expected net future value, and the Ramsey rule. Journal of Environmental Economics and Management. 2010;59:142-148.

[76] Liu C. Advanced progress of discount rate in climate change economics. Economic Dynamics. 2012;3:123-129 (In Chinese).

[77] Day JM, Daniel Wright P, Schoenherr T, Venkataramanan M, Gaudette K. Improving routing and scheduling decisions at a distributor of industrial gasses. Omega. 2009;37:227-237.

[78] Wei Y-M, Zou L-L, Wang K, Yi W-J, Wang L. Review of proposals for an agreement on future climate policy: Perspectives from the responsibilities for GHG reduction. Energy Strategy Reviews. 2013;2:161-168.

[79] Stanton EA, Ackerman F, Kartha S. Inside the integrated assessment models: Four issues in climate economics. Climate and Development. 2009;1:166-184.

[80] Negishi T. General equilibrium theory and international trade. Amsterdam, Netherlands: 
North-Holland Publishing Company; 1972.

[81] Peck SC, Teisberg T. $\mathrm{CO}_{2}$ concentration limits, the costs and benefits of control, and the potential for international agreement. Climate Change. 1995;31:19-34.

[82] Yang Z, Nordhaus WD. Magnitude and direction of technological transfers for mitigating GHG emissions. Energy Economics. 2006;28:730-741.

[83] Nakicenovic N, Grübler A, McDonald A. Global energy perspectives. Cambridge, UK: Cambridge University Press; 1998.

[84] Popp D. ENTICE: Endogenous technological change in the DICE model of global warming. Journal of Environmental Economics and Management. 2004;48:742-768.

[85] Dowlatabadi H. Sensitivity of climate change mitigation estimates to assumptions about technical change. Energy Economics. 1998;20:473-493.

[86] Gillingham K, Newell RG, Pizer WA. Modeling endogenous technological change for climate policy analysis. Energy Economics. 2008;30:2734-2753.

[87] Liang Q-M, Wei Y-M. Distributional impacts of taxing carbon in China: Results from the CEEPA model. Applied Energy. 2012;92:545-551.

[88] Burniaux J-M, Martin JP, Nicoletti G, Martins JO. GREEN a multi-sector, multi-region general equilibrium model for quantifying the costs of curbing $\mathrm{CO}_{2}$ emissions: A technical manual. OECD Economics Department Working Papers, OECD Publishing; 1992.

[89] MacCracken CN, Edmonds JA, Kim SH, Sands RD. The economics of the Kyoto Protocol. The Energy Journal. 1999;20:25-71.

[90] Buonanno P, Carraro C, Galeotti M. Endogenous induced technical change and the costs of Kyoto. Resource and Energy Economics. 2003;25:11-34.

[91] Nordhaus WD. Modeling induced innovation in climate-change policy. In: Grubler A, Nakićenović N, Nordhaus WD, editors. Technological change and the environment. Washington, DC: Resources for the Future Press; 2002. p. 259-290.

[92] Hedenus F, Azar C, Lindgren K. Induced technological change in a limited foresight optimization model. The Energy Journal. 2006:109-122.

[93] Bosetti V, Carraro C, Galeotti M. The dynamics of carbon and energy intensity in a model of endogenous technical change. The Energy Journal. 2006;27:191-206.

[94] Rotmans J. IMAGE: an integrated model to assess the greenhouse effect. New York: Springer; 1990.

[95] Pizer WA. Choosing price or quantity controls for greenhouse gases. In: Toman MA, editor. Climate Change Economics and Policy: An RFF Anthology. Washington, DC: RFF Press; 2001. p. 99-107.

[96] Weitzman ML. Prices vs. quantities. The review of economic studies. 1974;41:477-491.

[97] Pizer WA. Combining price and quantity controls to mitigate global climate change. Journal of Public Economics. 2002;85:409-434.

[98] Nordhaus WD. After Kyoto: Alternative mechanisms to control global warming. The American Economic Review. 2006;96:31-34.

[99] Cong R-G, Wei Y-M. Potential impact of (CET) carbon emissions trading on China's power sector: A perspective from different allowance allocation options. Energy. 2010;35:3921-3931.

[100] Cong R-G, Wei Y-M. Experimental comparison of impact of auction format on carbon allowance market. Renewable and Sustainable Energy Reviews. 2012;16:4148-4156. 
[101] Barrieu P, Fehr M. Market-consistent modeling for cap-and-trade schemes and application to option pricing. Operations Research. 2014;62:234-249.

[102] Zhu B, Wei Y. Carbon price forecasting with a novel hybrid ARIMA and least squares support vector machines methodology. Omega. 2013;41:517-524.

[103] Kanudia A, Shukla PR. Modelling of uncertainties and price elastic demands in energy-environment planning for India. Omega. 1998;26:409-423.

[104] Wu DD, Olson DL, Birge JR. Introduction to special issue on "Enterprise risk management in operations". International Journal of Production Economics. 2011;134:1-2.

[105] Wu DD, Chen S-H, Olson DL. Business intelligence in risk management: Some recent progresses. Information Sciences. 2014;256:1-7.

[106] Stern N. The structure of economic modeling of the potential impacts of climate change: grafting gross underestimation of risk onto already narrow science models. Journal of Economic Literature. 2013;51:838-859.

[107] Pindyck RS. Climate Change Policy: What do the models tell us? NBER Working Paper Series, National Bureau of Economic Research; 2013.

[108] Mastrandrea MD, Schneider SH. Probabilistic integrated assessment of" dangerous" climate change. Science. 2004;304:571-575.

[109] Yang M, Blyth W, Bradley R, Bunn D, Clarke C, Wilson T. Evaluating the power investment options with uncertainty in climate policy. Energy Economics. 2008;30:1933-1950.

[110] O'Neill BC, Riahi K, Keppo I. Mitigation implications of midcentury targets that preserve long-term climate policy options. Proceedings of the National Academy of Sciences of the United States of America. 2010;107:1011-1016.

[111] HaDuong M, Grubb MJ, Hourcade JC. Influence of socioeconomic inertia and uncertainty on optimal $\mathrm{CO}_{2}$-emission abatement. Nature. 1997;390:270-273.

[112] Tol RSJ. Welfare specifications and optimal control of climate change: An application of fund. Energy Economics. 2002;24:367-376.

[113] Nordhaus WD. An optimal transition path for controlling greenhouse gases. Science. 1992;258:1315-1319.

[114] Peck SC, Teisberg TJ. Cost-benefit analysis and climate change. Stanford University; 1993.

[115] Bréchet T, Camacho C, Veliov V. Model predictive control, the economy, and the issue of global warming. Annals of Operations Research. 2014;220:25-48.

[116] Persson TA, Azar C, Lindgren K. Allocation of $\mathrm{CO}_{2}$ emission permits: Economic incentives for emission reductions in developing countries. Energy Policy. 2006;34:1889-1899.

[117] Vaillancourt K, Waaub JP. A decision aid tool for equity issues analysis in emission permit allocations. Climate Policy. 2006;5:487-501.

[118] Mi Z-F, Pan S-Y, Yu H, Wei Y-M. Potential impacts of industrial structure on energy consumption and $\mathrm{CO}_{2}$ emission: a case study of Beijing. Journal of Cleaner Production. 2014:In press.

[119] Pearce D. The social cost of carbon and its policy implications. Oxford Review of Economic Policy. 2003;19:362-384.

[120] Wei Y-M, Liu L-C, Wu G, Zou L-L. Energy economics: $\mathrm{CO}_{2}$ emissions in China. New 
York: Springer; 2011.

[121] Roughgarden T, Schneider SH. Climate change policy: Quantifying uncertainties for damages and optimal carbon taxes. Energy Policy. 1999;27:415-429.

[122] Brannlund R, Nordstrom J. Carbon tax simulations using a household demand model. European Economic Review. 2004;48:211-233.

[123] van't Veld K, Plantinga A. Carbon sequestration or abatement? The effect of rising carbon prices on the optimal portfolio of greenhouse-gas mitigation strategies. Journal of Environmental Economics and Management. 2005;50:59-81.

[124] Mi Z-F, Zhang Y-J. Estimating the "value at risk" of EUA futures prices based on the extreme value theory. International Journal of Global Energy Issues. 2011;35:145-157.

[125] Mirzapour Al-e-hashem SMJ, Malekly H, Aryanezhad MB. A multi-objective robust optimization model for multi-product multi-site aggregate production planning in a supply chain under uncertainty. International Journal of Production Economics. 2011;134:28-42.

[126] Yau S, Kwon RH, Scott Rogers J, Wu D. Financial and operational decisions in the electricity sector: Contract portfolio optimization with the conditional value-at-risk criterion. International Journal of Production Economics. 2011;134:67-77.

[127] Tol RSJ. On the optimal control of carbon dioxide emissions: An application of FUND. Environmental Modeling and Assessment. 1997;2:151-163.

[128] Wing IS. Computable general equilibrium models and their use in economy-wide policy analysis. Technical notes series, MIT Joint Program on the Science and Policy of Global Change; 2004.

[129] Liang Q-M, Fan Y, Wei Y-M. Carbon taxation policy in China: How to protect energy-and trade-intensive sectors? Journal of Policy Modeling. 2007;29:311-333.

[130] Kokoski MF, Smith VK. A general equilibrium analysis of partial-equilibrium welfare measures: The case of climate change. The American Economic Review. 1987;77:331-341.

[131] Gottinger HW. Greenhouse gas economics and computable general equilibrium. Journal of Policy Modeling. 1998;20:537-580.

[132] Sherony KR, Knowles GJ, Boyd R. The economic-impact of crop losses: A computable general equilibrium approach. Western Journal of Agricultural Economics. 1991;16:144-155.

[133] Din AM. Global environmental-change data and modeling. LFIP Transactions A-Computer Science And Technology. 1992;13:625-634.

[134] Gerlagh R. A climate-change policy induced shift from innovations in carbon-energy production to carbon-energy savings. Energy Economics. 2008;30:425-448.

[135] Jorgenson DW, Goettle RJ, Hurd BH, Smith JB, Chestnut L, Mills D. US market consequences of global climate change. Arlington, TX: Pew Center on Global Climate Change; 2004.

[136] Kurosawa A. Carbon concentration target and technological choice. Energy Economics. 2004;26:675-684.

[137] Nordhaus WD, Popp D. What is the value of scientific knowledge? An application to global warming using the PRICE model. The Energy Journal. 1997;18:1-45.

[138] Sano F, Akimoto K, Homma T, Tomoda T. Analysis of technological portfolios for $\mathrm{CO}_{2}$ stabilizations and effects of technological changes. The Energy Journal. 2005:141-161.

[139] Rao S, Keppo I, Riahi K. Importance of technological change and spillovers in long-term climate policy. The Energy Journal. 2006;27:123-139. 
[140] Turton H. ECLIPSE: An integrated energy-economy model for climate policy and scenario analysis. Energy. 2008;33:1754-1769.

[141] Burniaux J-M, Truong TP. GTAP-E: An energy-environmental version of the GTAP model. GTAP Technical Papers, Purdue University; 2002.

[142] Jacoby HD, Reilly JM, McFarland JR, Paltsev S. Technology and technical change in the MIT EPPA model. Energy Economics. 2006;28:610-631.

[143] Kainuma M, Matsuoka Y, Morita T. Analysis of post-Kyoto scenarios: The AIM model. The Energy Journal. 1999:207-220.

[144] Manne A, Richels R. Buying greenhouse insurance: The economic costs of carbon dioxide emission limits. Cambridge, MA: MIT Press; 1992.

[145] Kemfert C. An integrated assessment model of economy-energy-climate: The model Wiagem. Integrated Assessment. 2002;3:281-298.

[146] Hope C, Anderson J, Wenman P. Policy analysis of the greenhouse effect: An application of the PAGE model. Energy Policy. 1993;21:327-338.

[147] Dowlatabadi H, Morgan MG. A model framework for integrated studies of the climate problem. Energy Policy. 1993;21:209-221.

[148] Barker T, Pan H, Köhler J, Warren R, Winne S. Decarbonizing the global economy with induced technological change: Scenarios to 2100 using E3MG. The Energy Journal. 2006;27:143-160.

[149] Mendelsohn R, Williams L. Comparing forecasts of the global impacts of climate change. Mitigation and Adaptation Strategies for Global Change. 2004;9:315-333.

[150] Schneider SH. Integrated assessment modeling of global climate change: Transparent rational tool for policy making or opaque screen hiding value - laden assumptions? Environmental Modeling \& Assessment. 1997;2:229-249. 